\title{
Late Precolonial Culinary Practices: Starch Analysis on Griddles from the Northern Caribbean
}

\author{
Andy J. Ciofalo ${ }^{1}$ (I) $\cdot$ Peter T. Sinelli ${ }^{2} \cdot$ Corinne L. Hofman $^{1}$ \\ Published online: 11 July 2019 \\ (C) The Author(s) 2019
}

\begin{abstract}
Late precolonial (c. 800-1500 CE) culinary practices in the northern Caribbean have received limited investigations. Determining foodways has been integral for the study of cultures, yet there has never been a comparison of foodway dynamics in the Caribbean between the Greater Antilles (the presumed origin of people who migrated into The Bahamas) and the Bahama archipelago. The objective of our study was to analyze microbotanical residues (starches) extracted from 45 clay griddles (food preparation platters) to illuminate a partial view of the phytocultural repertoire of this region and explicate variations of the identified culinary practices. The griddles were excavated from three archaeological sites: El Flaco and La Luperona in northwestern Dominican Republic and Palmetto Junction on the western coast of Providenciales, Turks \& Caicos Islands. Regarding the production of plant-based food on griddles, our produced data suggests that the people who lived at El Flaco focused on the production of maize (Zea mays L.) derivatives, La Luperona residents prepared guáyiga/coontie/ zamia (Zamia spp.) food products, and Palmetto Junction ostensibly had a focus on the production of manioc (Manihot esculenta Crantz) based foods. This survey of foodways has exposed particular cultural niches, different adaptation strategies, and associated culinary practices.
\end{abstract}

\section{Resumen}

Las prácticas culinarias precoloniales (c. 800-1500 CE) en el norte del Caribe han sido investigadas de manera limitida. Determinar lasdimensiones de la alimentación ha sido fundamental en el estudio de las culturas; no obstante, en el Caribe nunca se ha realizado unacomparación de estas dinámicas entre las Antillas Mayores (el atribuido origen migratorio de humanos a las Bahamas) y el archipiélago delas Bahamas. El objetivo de este estudio fue analizar los residuos microbotánicos (almidones) extraídos

Andy J. Ciofalo

a.j.ciofalo@arch.leidenuniv.nl

1 Faculty of Archaeology, Leiden University, Einsteinweg 2, 2333 CC Leiden, The Netherlands

2 Department of Anthropology, University of Central Florida, Orlando, FL 32816, USA 
de 45 burenes (platos depreparación de alimentos) para proporcionar una visión parcial del repertorio fitocultural de esta región y explicar las variaciones de laspracticas culinarias identificadas. Los burenes fueron excavados en tres sitios arqueológicos: El Flaco y La Luperona en el noroeste de laRepública Dominicana, y Palmetto Junction en la costa occidental de Providenciales, Islas Turcas y Caicos. En lo referente a la producciónde alimentos basados en las plantas, nuestros datos obtenidos en los burenes sugieren que las personas que vivieron en El Flaco seconcentraron en la producción de derivados del maíz (Zea mays L.); los residentes de La Luperona prepararon productos alimenticios deguáyiga/zamia (Zamia spp.); y en Palmetto Junction presumiblemente sus habitantes se enfocaron en la producción de alimentosderivados de yuca (Manihot esculenta Crantz). Este estudio de las dimensiones de la alimentación ha puesto de manifiesto la existenciade nichos culturales particulares, diferentes estrategias de adaptación, así como divergentes prácticas culinarias asociadas a ellas.

Keywords Starch analysis · Foodways · Caribbean archaeology $\cdot$ Griddles · Manioc · Cultural niche construction $\cdot$ Culinary practices

\section{Introduction}

The subject of foodways has been integral for reconstructing past lifeways. That which is eaten sustains communities both ideologically and corporally, because food is symbolically and factually representative of belief systems, social identity, and existence (Crouch and O'Neill 2000; Twiss 2007). Throughout the world, people have made the act of eating into a theater where a multitude of social relations can be symbolized, created, and strengthened or destroyed (Welch and Scarry 1995). Moreover, the social need for belonging has been assuaged through consumed food that was accepted at the community level (Dweba and Mearns 2011). Food has provided comfort and cemented or expressed group identity; therefore, the study of foodways can effectively illuminate socio-cultural structures that perpetuated learned behaviors. As such, understanding foods and their associated culinary practices can contribute towards interpreting identities. Through our study, a partial view of Caribbean Indigenous People's culinary practices became more evident.

Diet and subsistence patterns contribute a substantial amount of information for understanding people's lifeways. However, anthropologists have moved past attempts to determine which foods were featured in social organizations in favor of investigating the function of food as a part of the semiotic system within particular socio-cultural frameworks (Appadurai 1981; Morehart and Morell-Hart 2015; Morell-Hart 2012). Worldwide, more consistent applications and advances in archaeobotany have enabled archaeologists to address research problems regarding plant domestication, economies, subsistence strategies, human introductions of new plants, and the role of foods during social events (Barton and Torrence 2015; Henry et al. 2014; Liu et al. 2018; PagánJiménez et al. 2015; Pearsall 2018; Piperno 2011; Zarrillo et al. 2018). This improved methodology facilitates a more comprehensive conceptualized view of foodways to include not only dietary elements but also the profusion of related behaviors including production, preparation, storage, and presentation of foods. To disentangle human-plant interrelationships, archaeobotanical interpretations need well-grounded data generated 
from systematic investigations, and we postulate that determining past phytocultural ${ }^{1}$ scenarios through empirical evidence should be at the forefront of research on archaeological foodways.

In the Caribbean, plants were an agroeconomic foundation, connected with ceremonial, civic, and daily activities by providing foods, medicine, and materials for craft production (Newsom and Wing 2004). Pearsall $(1983,1985)$ researched macroremains and initiated full-fledged, systematic, paleoethnobotanical analyses in the Caribbean. Subsequently, Newsom $(1988,1991,1992,1993)$ began to identify archaeological plant macro remains from Haiti, followed by Puerto Rico, Bonaire, and the Lesser Antilles. Macrobotanical research in the Neotropics provided useful information but did not recover empirical evidence for many of the presumed key agroeconomic plants (Dickau 1999; Newsom 1988, 1991, 1992; Newsom and Wing 2004; Piperno and Pearsall 1998). Moreover, tropical regions are notorious for poor organic preservation (Pearsall 2003), and suitable macrobotanical data can be unrecoverable in these contexts. During this time, Pearsall (1989) expanded her research area into The Bahamas combining macroremains and phytolith analyses.

More recently, other plant microfossils have been studied in the Caribbean (CastillaBeltrán et al. 2018) and particularly starch analyses of these plant remains have been profitably utilized to reconstruct the archaeobotanical record and culinary practices (Ciofalo et al. 2018; Pagán-Jiménez 2016; Pagán-Jiménez et al. 2015; van den Bel et al. 2018). For the first time, we are now systematically applying microbotanical analyses in the northern Caribbean with comparisons amongst sites and between islands. This approach produces empirical evidence for making well-grounded interpretations regarding functions of plant-based foods in cultural frameworks of tropical regions.

We provided direct archaeological evidence of human-plant interactions determined from microbotanical residues (starches) extracted from 45 clay griddles (flat "cooking", plates). We excavated griddles from three archaeological sites: El Flaco and La Luperona in the Dominican Republic and Palmetto Junction in the Turks \& Caicos Islands. Our collated data and interpretations add to ongoing discussions regarding the roles of plants in transported landscapes, niche constructions, and culinary practices (Berman and Pearsall 2008; Laffoon et al. 2016; Mickleburgh et al. 2019; Mickleburgh and Pagán-Jiménez 2012; Pagán-Jiménez 2013; Rodríguez Ramos 2011; Smith 2015, 2016; Smith and Chinique de Armas 2018; Zeder 2016).

\section{Regional Background}

The deep history of the northern Caribbean is brimming with rich culinary practices (Newsom and Wing 2004, 114-188; Pagán-Jiménez 2013; Smith and Chinique de Armas 2018). The excitement has been exponential as researchers expand upon and contrast with European written sources, demonstrating the immense diversity of culinary practices that were present in Neotropical regions (Berman and Pearsall 2008; Morehart and Morell-Hart 2015; Newsom 2008; Pagán-Jiménez 2007; Piperno et al.

\footnotetext{
${ }^{1}$ For the purpose of our research, phytocultural has been defined as human-plant interrelationships which is a broad category including a plethora of related botanical foodways.

${ }^{2}$ Prior to deposition into the archaeological record, some griddles may have been used as surfaces to process plants without cooking similar to modern kitchen countertops (Rodríguez Suarez and Pagán-Jiménez 2008); thus, some griddles may have been used as flat food preparation plates that did not involve cooking.
} 
2009; Rodríguez Ramos 2016; Sheets et al. 2012; Staller et al. 2006). For the Caribbean, Pané (1999 [1571]) and Las Casas (1909) wrote descriptions of the use of manioc (Manihot esculenta Crantz), sweet potato (Ipomoea batatas L.), maize (Zea mays L.), and coontie/guáyiga/zamia (Zamia spp.). ${ }^{3}$ These writings portrayed what Europeans believed were the dietary and symbolic significances of plants for the Caribbean Indigenous Peoples. However, it is errant to project ethnohistoric sources onto the past in an attempt to elucidate the archaeological record (Wobst 1978; Wylie 1985). Extrapolations of contact period written sources applied to the archaeological record from centuries before are problematic due to cultural changes (i.e., which plants were used and how they were processed) due to the magnitude of disruption from European invasions, systematic colonization, and enslavements (Denevan 1992; Jennings 1975; Keegan 1996; Montenegro and Stephens 2006; Pagán-Jiménez 2009; Wilson 1993). For these reasons, we turned to archaeological data to illuminate phytocultural scenarios of a region in the northern Caribbean during the advent of European invasions.

Traditionally, archaeologists have believed that as indigenous "horticultural" schemes were being maximized during the Late Ceramic Age (c. 800-1500 CE), they evolved into "agricultural" systems and created surpluses of crops, such as manioc (Keegan 1996, 2000; Newsom and Wing 2004:189). Manioc use by precolonial Caribbean people has been primarily assumed from ethnohistoric written sources, as well as the presence of microlithic grater chips, shell tools, and clay griddles (Crock and Bartone 1998; Fernández de Oviedo 1851 [1535]; Las Casas 1909:32; Loven 1935:359-366; Newsom and Wing 2004; Rouse 1992:12). These plant-processing tools, supposedly related with manioc, have often been regarded as carrying out a single function and processing one type of plant (see DeBoer 1975; Rouse 1992; Wilson 2007). Due to the abundance of these types of artifacts, it was assumed that manioc was an integral part of precolonial subsistence patterns in the Caribbean (Allaire 1999; Wilson 2007:86). However, regarding archaeological manioc starches from the Greater Caribbean region, ${ }^{4}$ they have been recovered from the artifacts listed in Table 1.

Prior to our current study, out of 30 clay griddles from the Caribbean, Venezuela, and French Guiana that have been analyzed for starch content, five have demonstrated evidence for manioc remains (McKey et al. 2010; Pagán-Jiménez in Oliver 2014; Pagán-Jiménez in Ulloa Hung 2014:115,138; Pagán-Jiménez 2008, 2009, 2011a, b, 2012; Rodríguez Suárez and Pagán-Jiménez 2008; van den Bel et al. 2013). Rodríguez Suárez and Pagán-Jiménez (2008) analyzed five clay griddles and recovered starches from a variety of species but no manioc starch, their study also proved that starches preserved and could be recovered from charred remains on griddles (see also Zarrillo et al. 2008). In sum, although long assumed to have been a staple cultigen, manioc has been sporadic or virtually invisible in the data generated from microbotanical investigations in the northern Caribbean and absent from griddles that have been analyzed for starch content (Berman and Pearsall 2000; Berman and Pearsall 2008; Chinique de Armas et al. 2015; González Herrera 2016; Mickleburgh and Pagán-Jiménez 2012; Pagán-Jiménez in Ulloa Hung 2014:115,138; Pagán-Jiménez 2007, 2008, 2009, 2011a;

\footnotetext{
${ }^{3}$ Plants of the genus Zamia are known locally in The Dominican Republic as guáyiga and in The Bahamas as coontie, and thus, the term zamia is used to denote plants of this genus in the rest of this article.

${ }^{4}$ The Greater Caribbean (pan-Caribbean) region has been envisioned geographically as the seascape and continental areas proximally surrounding the insular Caribbean islands (Rodríguez Ramos 2010).
} 
Table 1 Manioc starch recoveries from Greater Caribbean archaeological contexts

\begin{tabular}{|c|c|c|c|}
\hline Location & Type of artifact & $\begin{array}{l}\text { No. of } \\
\text { recovered manioc } \\
\text { starches }\end{array}$ & Reference \\
\hline Panama & Lithic grinding base & $5(\mathrm{~S})$ & Piperno and Holst (1998) \\
\hline Panama & $\begin{array}{l}\text { Lithic chopper } \\
\text { Lithic grinding base }\end{array}$ & $5(\mathrm{~S})$ & Dickau et al. (2007) \\
\hline French Guiana & 3 Clay griddles & $7(\mathrm{~S})$ & McKey et al. (2010) \\
\hline French Guiana & Clay bowl & $2(\mathrm{~S})$ & Pagán-Jiménez (2012) \\
\hline French Guiana & Clay griddle & $1(\mathrm{~S})$ & van den Bel et al. (2013) \\
\hline Venezuela & $\begin{array}{l}\text { Clay griddle, } 2 \text { clay } \\
\text { pots }\end{array}$ & NA & Pagán-Jiménez in Oliver (2014) \\
\hline Colombia & Handstone & NA & Piperno and Pearsall (1998:200) \\
\hline Colombia & $\begin{array}{l}\text { Lithic grinding base } \\
\text { Lithic chopper } \\
3 \text { Handstones }\end{array}$ & $13(\mathrm{~S})$ & Aceituno and Loaiza (2014) \\
\hline Belize & Lithic biface & $2(\mathrm{~T})$ & Rosenswig et al. (2014) \\
\hline Guatemala & $\begin{array}{l}2 \text { Lithic handstones } \\
2 \text { Metates } \\
\text { Clay jar }\end{array}$ & $\begin{array}{l}19(\mathrm{~S}), 5(\mathrm{~T}) \\
27(\mathrm{~S}) \\
1(\mathrm{~S}), 1(\mathrm{~T})\end{array}$ & Cagnato and Ponce (2017) \\
\hline Panama & Lithic grinding base & $1(\mathrm{~S})$ & Aceituno and Martín (2017) \\
\hline Puerto Rico & 2 Handstones & $4(\mathrm{~T})$ & Pagán-Jiménez et al. (2005) \\
\hline Puerto Rico & Coral milling base & Several (T) & Pagán-Jiménez (2007:127) \\
\hline Puerto Rico & $\begin{array}{l}\text { Handstone } \\
2 \text { Lithic grinding } \\
\text { bases }\end{array}$ & $\begin{array}{l}3(\mathrm{~S}) \\
1(\mathrm{~S}), 4(\mathrm{~T})\end{array}$ & Pagán-Jiménez and Oliver (2008) \\
\hline Puerto Rico & Clay pot & $1(\mathrm{~S})$ & Pagán-Jiménez (2011a) \\
\hline Aruba & Dental calculus & $1(\mathrm{~S})$ & $\begin{array}{l}\text { Mickleburgh and Pagán-Jiménez } \\
\text { (2012) }\end{array}$ \\
\hline Dominican Republic & Clay vessel & $\begin{array}{l}1(\mathrm{~S}) \\
1(\mathrm{~T})\end{array}$ & $\begin{array}{l}\text { Pagán-Jiménez in Ulloa Hung } \\
\qquad(2014: 138)\end{array}$ \\
\hline Martinique & Clay pot & $1(\mathrm{~S})$ & Pagán-Jiménez (2016) \\
\hline $\begin{array}{l}\text { Long Island, The } \\
\text { Bahamas }\end{array}$ & $\begin{array}{l}\text { Shell artifact } \\
\text { Microlith }\end{array}$ & $\begin{array}{l}32(\mathrm{~S}), 6(\mathrm{~T}) \\
11(\mathrm{~S}), 2(\mathrm{~T})\end{array}$ & Ciofalo et al. (2018) \\
\hline
\end{tabular}

$S$ secure identification, $T$ tentative identification

Rodríguez Suárez and Pagán-Jiménez 2008). Starch analyses that have been carried out within the Greater Caribbean region also do not support the traditionally assumed view that manioc was a dietary staple (see discussions on this in Pagán-Jiménez 2013; Pagán-Jiménez et al. 2017; Perry 2002, 2005).

Preconceptions regarding the dietary role of maize, envisioned it as a restricted crop, or of less value than manioc for the Caribbean Indigenous Peoples (Loven 1935:370; Newsom and Wing 2004:155; Rouse 1992:12). However, maize has consistently been one of the most ubiquitous plants represented by recovered starch residues from various 
studies throughout the Caribbean (Berman and Pearsall 2008; Ciofalo et al. 2018; Mickleburgh and Pagán-Jiménez 2012; Pagán-Jiménez 2007, 2013). The labels of ubiquitous, staple, and major dietary components should not obscure the nature of diverse vegetal subsistence for the precolonial Caribbean (Pagán-Jiménez 2007, 2013; Rodríguez Ramos et al. 2013b). The broad spectrum of plants prepared in the Caribbean has become apparent particularly from archaeobotanical investigations of griddles (McKey et al. 2010; Pagán-Jiménez 2008, 2012, 2013; Rodríguez Suárez and Pagán-Jiménez 2008).

The multifunctional use of griddles was first determined from the use of gas chromatography that exposed the presence of both plant and animal lipids (Rodríguez Suárez 2001, 2004). However, it was several years until the diversity of plants prepared on griddles was ascertained (Pagán-Jiménez 2007; Rodríguez Suárez and Pagán-Jiménez 2008). Rodríguez Suárez and Pagán-Jiménez (2008) validated that griddles were used to prepare sweet potato, arrowroot (Maranta arundinacea L.), bean (Phaseolus vulgaris L.), cocoyam (Xanthosoma sp.), zamia, and maize. The discovery of maize prepared on griddles in the Caribbean contradicted the presumptions of a few archaeologists (e.g., Newsom 2006, 2008; Newsom and Deagan 1994; Newsom and Pearsall 2003; Rouse 1992). It is now evident that an attributed function of an artifact based on morphology alone or artifact assemblages are not reliable indicators of precolonial culinary practices. To summarize, the current understanding of phytocultural scenarios within the northern Caribbean during the late precolonial period included humans who cultivated, processed, and consumed crop species such as maize, sweet potato, leren (Calathea allouia (Aubl.) Lindl.), yam (Dioscoreaceae), cocoyam, and arrowroot (Marantaceae) in addition to collecting and possibly managing wild (or semi-wild) plants such as zamia and wild bean (Phaseolus vulgaris L.) (Berman and Pearsall 2000; Berman and Pearsall 2008; Chinique de Armas et al. 2015; González Herrera 2016; Mickleburgh and Pagán-Jiménez 2012; Pagán-Jiménez 2007, 2009).

Our case study of griddle use in the northern Caribbean was designed to expose how indigenous socio-cultural behaviors associated with this specialized food-processing tool were employed and which plants were parts of the culinary repertoire in the northern Caribbean. Culinary practices are another line of evidence revealing the immense diversity of Caribbean Indigenous Peoples. If the culinary practices that involved griddles were successfully shared in the region of interest, then similar starchy plants and associated potential foodways ranking positions should be identified. On the contrary, if these culinary practices were unsuccessful amongst these communities, then we would expect to find limited use of griddles and/or evidence of dissimilar types of starchy plants recovered. If any of these assumptions are supported, then plausible interpretations may be developed, further informing us about culinary practices.

To better comprehend foodways at different geographical scales, we compared botanical foodways of intra- and inter-islands/sites in the northern Caribbean with overlapping occupation dates. Since 2013, Leiden University within the NEXUS1492 synergy project, under the direction of Prof. dr. Corinne Hofman, has carried out archaeological research in northwestern Dominican Republic. Prior to and more recently within the NEXUS1492 synergy project, Dr. Jaime Pagán-Jiménez has developed archaeobotanical criteria for foodways research in Dominican Republic and the Greater Caribbean region. Our present study incorporated those developed criteria for the selection of artifacts we sampled that would facilitate a comparison of foodways between the archaeological sites of El Flaco, La Luperona, and Palmetto Junction. The 
aim of this comparison of botanical foodways was to reconstruct cultural niches, adaptation strategies, culinary practices, and likely transported landscapes.

\section{Archaeological Settings}

\section{Northern Dominican Republic}

The archaeological sites of El Flaco and La Luperona are located in northwestern Dominican Republic and have been interpreted as hamlets of permanent households occupied during the thirteenth to fifteenth centuries (Hofman and Hoogland 2015; Hofman et al. 2018). Situated between the Cibao valley and the Cordillera Septentrional, El Flaco is located $300 \mathrm{~m}$ above mean sea level and $20 \mathrm{~km}$ from the current coast (Hofman and Hoogland 2015). The ecotone of the southern side of the Cordillera Septentrional, where El Flaco is situated, is primarily a subtropical dry forest, but transitional with subtropical moist forest (Moya Pons 2004:32-33). El Flaco's material culture remains are characterized by pottery from both the Chican and Meillacan subseries and other pottery with interpreted mixed features of these two subseries (Hofman and Hoogland 2015; Jacobson n.d.). Beyond dietary plants, archaeological evidence from a predominance of endemic rodent, avian, and reptile remains in the faunal assemblage compared to that of marine-sourced remains suggests that the inhabitants of El Flaco focused on consumption of terrestrial animals (Shev 2018:177).

La Luperona is located $8 \mathrm{~km}$ north of El Flaco across the Cordillera Septentrional and is within view of and approximately $18 \mathrm{~km}$ from the coastal zone. The ecotone of the northern side of the Cordillera Septentrional, where La Luperona is situated, is primarily a subtropical moist forest, but transitional with subtropical very moist forest (Moya Pons 2004:32-33). The material culture remains are characterized primarily by pottery from the Meillacan subseries (Hofman and Hoogland 2015). However, evidence from pottery paste recipes implied there was an exchange of products and/or knowledge between La Luperona and El Flaco (Ting et al. 2016). This web of practitioners who shared clay recipes could have also shared foodways incorporating prepared meals on the pottery available in their social network. Although, having similar cultural materials do not always suggest similar foodways and the selection or rejection of food takes place at the level of self on a quotidian basis, these decisions may be reinforced at the community level during practices of eating together (Bourdieu 1979; Mintz 1985:4). Local environmental conditions are varied between these archaeological sites, so it would not be surprising if some plants were more successfully grown than others at the different locations (Fuente García 1976; Moya Pons 2004; Reyna Alcántara and Polonia Martínez 2012).

\section{The Bahamas \& Turks and Caicos Islands}

It is widely believed that the Turks \& Caicos islands functioned as an interaction hub for the proximal region of influence for Hispaniola (comprised of modern day Haiti and Dominican Republic) (Berman et al. 2013; Keegan 2007; Keegan and Hofman 2017:172; Keegan et al. 1998; Morsink 2012; Sinelli 2010, 2013). Since 2014, the University of Central Florida, under the direction of Pete Sinelli and Andy Ciofalo, has carried out archaeological research at the Palmetto Junction site. A series of 


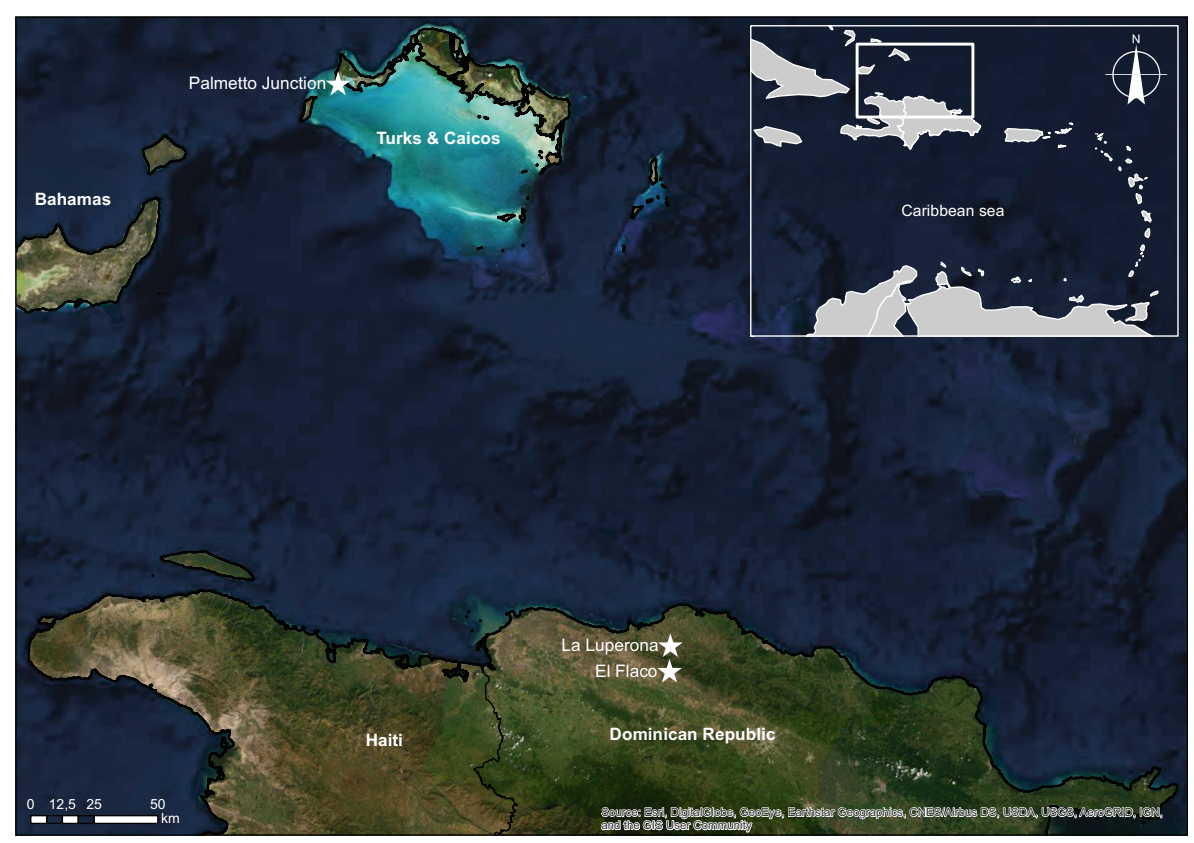

Fig. 1 Map of northern Caribbean showing the location of El Flaco, La Luperona, and Palmetto Junction. Prepared by Dr. Eduardo Herrera Malatesta

radiocarbon dates cal 1334-1440 $\mathrm{CE}^{5}$ indicate that Palmetto Junction was regularly occupied for approximately 100 years (Sinelli 2015) and was contemporaneous with the Dominican Republic sites in the current study. The site of Palmetto Junction is located on a narrow isthmus on the western end of Providenciales, Turks \& Caicos Islands (Fig. 1). This site is characterized by a high frequency and robust density of Palmetto Ware style pottery sherds covering its surface and throughout the investigated archaeological contexts. Amongst the largest sites in the Bahama archipelago, ${ }^{6}$ Palmetto Junction encompasses nearly 2 ha of confirmed activity areas and likely households. There are more than 20 middens of dense deposits containing abundant faunal remains, pottery sherds, and other material culture remains. Reef fish from the faunal assemblage have been interpreted to have contributed a significant portion to the Indigenous People's diet at Palmetto Junction (DuChemin 2005). However, there is also significant evidence of hutia (Geocapromys ingrahami) being exploited for food and possibly management by humans; indeed, more hutia remains have been recovered from Palmetto Junction than at any other site excavated so far in the Bahama archipelago (LeFebvre et al. 2018). Currently, the Turks \& Caicos Islands are located within

\footnotetext{
$\overline{{ }^{5} \text { Lab no. Beta-384,425, } 660 \pm 30}$ BP, cal CE 2-sig (IntCal 13) and Lab no. Beta-384,427, $460 \pm 30$ BP, cal CE 2-sig (IntCal 13).

${ }^{6}$ The Bahama archipelago designates a geographical area with two independent nations: the Commonwealth of the Bahamas and the Turks \& Caicos Islands. Therefore, Providenciales is geographically the southern Bahamas.
} 
the Bahamas Zone III and considered dry tropical forest ecotone (Sears and Sullivan 1978). However, it is problematic to extend modern environmental records to the past; it is still a necessity to help understand a range of possibilities for precolonial environments and plausible ethnobotanical settings.

More than $90 \%$ of the thousands of pottery sherds recovered at Palmetto Junction were of the Palmetto Ware style (Sinelli 2015). Chican and Meillacan pottery account for the remainder of the assemblage. Wild cotton (Gossypium spp.), manioc, and chili pepper (Capsicum spp.) presently grow across the site without human intervention and likely have descended from plants originally cultivated by Indigenous Peoples who lived there centuries ago. The size of Palmetto Junction and the density of both hutia and pottery remains make it unique amongst Bahamian archaeological sites. The location of Palmetto Junction is ideally positioned to maximize access to local clay, both botanical and animal resources, as well as to facilitate contact with people further North in The Bahamas or further South in the Greater Antilles.

\section{Scope of Study}

Niche construction is a theory used to clarify how and why an organism transformed, shaped trajectories, and adapted within their own local environments (Odling-Smee et al. 2003; Smith 2016; Zeder 2016). The effectiveness of human niche construction is founded on the capacity for culture, which includes high levels of cooperation (Laland and O'Brien 2010). Previously, the human niche has been defined as culture (Downs and Bleibtreu 1972), and a "cultural niche" may be considered as the way an organism made a living (Lambert 2018). The epitome or perhaps primary building blocks for constructing how humans make a living are food products.

Regarding plant-based food products, several human-environmental interrelationships need to be fulfilled to solidify foundations of a constructed, preferred diet. Firstly, landscapes must be transformed to create appropriate socio-environmental conditions for different types of foods. Secondly, multidimensional human-environmental relationships at different geographical scales help the niche constructors adapt, incorporate, and reinforce successful foodways. This context of food creation, specifically the ways of preparing food products with a widely used culinary tool (griddle), may reveal one of the most crucial stages ever produced by a cultural niche - the humanization and devouring of the landscape.

For our study, the examined cultural niche was the way humans created starchy foods using griddles. Even if the creators did not consume the prepared foods, the finished products could have been traded with local or regional communities, and thus a part of their constructed niche, to make a living. If the culinary practices were successful, cultural transmissions could positively reinforce these practices in local or regional communities. Alternatively, if they were unsuccessful, new culinary practices should emerge (Eerkens and Lipo 2005; Zeder 2016). To investigate this idea, we carried out multiscalar analyses of botanical foodways with a focus on clay griddles because griddles were one of the common food preparation implements archaeologically recovered from most Ceramic Age Caribbean sites and all three sites in our study. 
Table 2 Samples by site, lab identification, and provenance (ZSSQ is zone, sector, and square locations)

\begin{tabular}{|c|c|c|c|c|c|}
\hline Site El Flaco & $\begin{array}{l}\mathrm{L} \text { a b } \\
\text { ID }\end{array}$ & Find No. & Feature Type & $\begin{array}{l}\text { Un it } \\
\text { No. }\end{array}$ & Field Provenance and Layer \\
\hline & 27 & 2596 & None & 77 & ZSSQ 63-54-37 \\
\hline & 550 & 1461 & None & 34 & ZSSQ 63-47-81, L. 1 \\
\hline & 558 & 2456 & None & 73 & ZSSQ 63-73-38, L. 2 \\
\hline & 576 & 2229 & None & 60 & ZSSQ 63-38-9, L. 1 \\
\hline & 585 & 2374 & None & 68 & ZSSQ 63-45-52, L. 2 \\
\hline & 601 & 1577 & None & 32 & ZSSQ 63-82-57, L. 6 \\
\hline & 612 & 1562 & None & 33 & ZSSQ 63-83-62, L. 5 \\
\hline & 631 & N/A & None & 70 & ZSSQ 63-73-9, L. 4 \\
\hline & 632 & 2709 & None & 70 & ZSSQ 63-73-18, L. 4 \\
\hline & 782 & 1265 & None & 19 & ZSSQ 63-67-24 L. 6 \\
\hline & 788 & 1219 & None & 30 & $\begin{array}{l}\text { ZSSQ 63-66-28 L. Comb } \\
\text { Layers }\end{array}$ \\
\hline & 792 & 806 & None & 13 & U. 13 ZSSQ 63-56-78 L. 2 \\
\hline & 795 & 1181 & None & 30 & $\begin{array}{l}\text { U. } 30 \text { ZSSQ 63-56-84 L. Comb } \\
\text { Layers }\end{array}$ \\
\hline & 796 & 27 & None & 1 & U. 1 ZSSQ 63-64-94 L. 6 \\
\hline & 797 & 8115 & None & 13 & U. 13 ZSSQ 63-56-87 L. 4 \\
\hline \multirow[t]{16}{*}{ La Luperona } & $\begin{array}{l}\text { Lab } \\
\text { ID }\end{array}$ & Find No. & Feature Type & $\begin{array}{l}\text { Unit } \\
\text { No. }\end{array}$ & Field Provenance and Layer \\
\hline & 1 & 49 & Fill & 3 & $30-40 \mathrm{cmbs}$ \\
\hline & 2 & 25 & No record & 1 & ZSSQ 54-47-75, L. 4 \\
\hline & 3 & 25 & No record & 1 & ZSSQ 54-47-75, L. 4 \\
\hline & 4 & 25 & No record & 1 & ZSSQ 54-47-75, L. 4 \\
\hline & 5 & 93 & Fill & 3 & 40-50 cmbs, Fill 3 \\
\hline & 6 & 14 & None & 1 & ZSSQ 54-47-75, L.3 \\
\hline & 8 & 12 & Fill & 1 & ZSSQ 50-47-76, L. 3 \\
\hline & 10 & 29 & None & 1 & ZSSQ 54-47-75, L. 5 \\
\hline & 11 & 54 & Fill & 3 & $40-50 \mathrm{cmbs}$ \\
\hline & 13 & 10 & None & 1 & ZSSQ 54-47-66, L. 2 \\
\hline & 14 & 16 & None & 1 & ZSSQ 54-47-66, L. 3 \\
\hline & 15 & 21 & None & 1 & ZSSQ 54-47-66, L. 4 \\
\hline & 17 & N/A & None & 1 & ZSSQ 54-47-65, L. 4 \\
\hline & 18 & 4 & None & 1 & ZSSQ 54-47-75, L. 1 \\
\hline & 19 & 6 & NA & 1 & ZSSQ 54-47-76, L. 2 \\
\hline \multirow[t]{7}{*}{$\begin{array}{l}\text { Palmetto } \\
\text { Junction }\end{array}$} & $\begin{array}{l}\text { Lab } \\
\text { ID }\end{array}$ & $\begin{array}{l}\text { Field Specimen } \\
\text { No. }\end{array}$ & Feature Type & Unit & Field Provenance and Layer \\
\hline & 102 & 118 & Midden & $\mathrm{U}$ & 20 cmbs L. 3 \\
\hline & 103 & 119 & Midden & $\mathrm{U}$ & $30 \mathrm{cmbs}$ L. 4 \\
\hline & 104 & 119 & Midden & $\mathrm{U}$ & 30 cmbs L. 4 \\
\hline & 105 & 125 & Midden & $\mathrm{V}$ & 40 cmbs L. 5 \\
\hline & 106 & 125 & Midden & $\mathrm{V}$ & $40 \mathrm{cmbs}$ L. 5 \\
\hline & 107 & 126 & Midden & $\mathrm{V}$ & $50 \mathrm{cmbs}$ L. 6 \\
\hline
\end{tabular}


Table 2 (continued)

\begin{tabular}{|c|c|c|c|c|c|}
\hline Site El Flaco & $\begin{array}{l}\mathrm{L} a \mathrm{~b} \\
\text { ID }\end{array}$ & Find No. & Feature Type & $\begin{array}{l}\text { Un it } \\
\text { No. }\end{array}$ & Field Provenance and Layer \\
\hline & 108 & 126 & Midden & $\mathrm{V}$ & $50 \mathrm{cmbs}$ L. 6 \\
\hline & 127 & 118 & Midden & $\mathrm{U}$ & 20 cmbs L. 3 \\
\hline & 128 & 127 & Midden & V & 60 cmbs L. 7 \\
\hline & 129 & 134 & Midden & $\mathrm{X}$ & 2 cmbs L. 1 \\
\hline & 130 & 132 & Midden & W & $40 \mathrm{cmbs}$ L. 5 \\
\hline & 132 & 131 & Midden & W & $30 \mathrm{cmbs}$ L. 4 \\
\hline & 133 & 136 & $\begin{array}{l}\text { Inside combustion } \\
\text { feature }\end{array}$ & $\mathrm{X}$ & $20 \mathrm{cmbs}$ L. 3 \\
\hline & 136 & 142 & Midden & Z & $31 \mathrm{cmbs}$ L. 2 \\
\hline & 138 & 143 & Midden & $\mathrm{Z}$ & $41 \mathrm{cmbs}$ L. 3 \\
\hline
\end{tabular}

\section{Materials and Methods}

\section{Artifact Management and Sample Extraction}

We chose 15 griddle finds that consisted of a clay fragment or multiple fragments from each archaeological site because La Luperona had this amount recovered which was the fewest griddle finds recovered from any of the three sites, but it means $100 \%$ of griddle finds from La Luperona were sampled (Table 2). Because the sampled griddles were recovered from three separate archaeological sites and were likely produced by different communities of potters, they did not have the same color clay or surface treatments (e.g., did not have visible slip or paint and $20 \%$ of sampled griddles from Palmetto Junction had weaving impressions on the presumed bases). However, all sampled griddles were flat, thick (average thickness was greater than $2 \mathrm{~cm}$ ), and macroscopically porous. In addition, the sampled griddles were similar to ethnographic descriptions of some clay griddles: large (2-4-cm thick), flat, and made of coarse clay (Loven 1935:367; Pennington 1963:217; van den Bel 2009). Because we had tight control over the excavations and observed the recovery of all clay sherds, this reduced the possibility the same griddle was sampled twice. When we recovered griddle sherds from the same unit and stratigraphic layer, if they fit together and were possibly fragments of the same griddle, we sampled and treated them as the same griddle find. The majority of the sampled griddles were large, thick, and flat enough that it was impossible they came from flat-bottomed bowlshaped vessels. As it has been extensively demonstrated in Caribbean archaeology (Hoogland and Hofman 1993; Keegan and Hofman 2017:91; Rouse 1941:92; Winter 1978), precolonial clay griddles are the only tools in the region having such morphometric characteristics. These characteristics are also in accordance with ethnohistoric descriptions of griddles (Fernández de Oviedo 1959 [1526]; Las Casas 1909).

Of the three sites, El Flaco had the most fieldwork seasons carried out and more than 150 separate griddle finds were isolated and sampled for microbotanical residues. Of all the sampled griddle finds at El Flaco, the 50 recovered outside of features were targeted for this study. Palmetto Junction had 30 griddle finds isolated and sampled for microbotanical residues. For each site, during archaeological recovery, we isolated 
the griddle finds and stored them in new plastic bags. We then assigned each griddle find a starch-lab identification number. Also, we entered the selected griddle sample identification numbers into a random number generator on random.org (Haahr and Haahr 2018). Finally, we randomly generated 15 integers, applied them to the samples from El Flaco and Palmetto Junction, and subsequently processed and used them along with all of the La Luperona griddle samples for our research (Table 2).

The samples from this analysis $(\sim 0.214 \mathrm{~g}$ each $)$ come from sediment obtained from dry-scraping the used surfaces of the griddle fragments. The procedures we followed were primarily after Pagán-Jiménez (2007), and we included slight modifications based on Atchison and Fullagar (1998), Pagán-Jiménez et al. (2015), Pearsall et al. (2004), Zarrillo (2012), and Zarrillo et al. (2008). The starch extraction protocol first called for us to lightly wash each artifact with distilled water. This washing procedure removed much of the sediment that adhered to the griddle fragments post-depositionally and was likely not a part of the artifact's use-history (Barton and Torrence 2015). Then, we used a wash bottle with distilled water with significant water pressure for a final rinse, which likely removed the majority of any possible post-depositional contamination, excavation contamination, and post-excavation contamination (Hart 2011). This washing procedure was also necessary to improve the reliability of accessing the griddles regular (original surface) and negative surfaces (cracks, crevices, fissures, holes, and pores).

We dry-scraped the sampled surfaces of each griddle with a sterilized dental pick in its entirety to the depth of approximately $1 \mathrm{~mm}$, unless the fragment was larger than $5 \mathrm{~cm}^{2}$. In the cases of larger fragments, we scraped a systematic grid-like pattern in approximated areas of $1 \times 1 \mathrm{~cm}$ and roughly, to the depth of $1 \mathrm{~mm}$, which helped obtain a representative sample of each large griddle fragment. We collected the scraped residues on new printing paper and funneled them into new 1.5-ml vials. Between the times we sampled each artifact, we washed all lab surfaces, hands, and instruments used with distilled water to prevent cross-contamination between samples. We payed particular attention to cleaning the used dental pick by applying high-pressured distilled water from a wash bottle and heat from a lighter until red hot, which removed and/or destroyed starches that possibly remained on the dental pick (Pagán-Jiménez et al. 2015; Zarrillo et al. 2008).

For our study, we did not investigate any sediment samples from the artifact contexts for starch content. The rationale regarding sampling soil near an artifact was that if residues found on artifacts are not apparent in the soil, then the starches extracted from the artifact's surfaces were more likely to have resulted from use of the artifact. Other studies determined starches recovered from sediments that were near an artifact related to transference from the artifact to the surrounding soils (Ma et al. 2017; Pearsall et al. 2004; Piperno et al. 2000). However, we excavated the artifacts from Palmetto Junction from classic middens, which concerned us because of the possibility for ancient depositional contamination. Therefore, we sampled and analyzed a few non-culturally modified objects (hand-sized lithics without macroscopic use-wear traces) from the middens at Palmetto Junction for starch content. We detected no starches from these control samples.

\section{Heavy Density Liquid Separation for the Recovery of Ancient Starches}

We transferred sediment samples from the griddles to the labs at Leiden University and subjected them to a flotation procedure to separate starches from the rest of the material. We applied this part of the procedure primarily after Pagán-Jiménez (2007) and 
modified from Atchison and Fullagar (1998), Barton et al. (1998), Dickau (2005), Henry et al. (2016), Pearsall et al. (2004), Perry (2010), Therin et al. (1999), Zarrillo (2012), and Zarrillo et al. (2008). We prepared a solution of heavy-liquid cesium chloride $(\mathrm{CsCl})$ to $1.79 \mathrm{~g} / \mathrm{cm}^{3}$ and subsequently added it to each vial. We then placed each vial into an ultrasonic bath for $1 \mathrm{~min}$. We deemed this ultrasonic step necessary for two reasons. First, it assisted in breaking apart any carbonized and conglomerated residues. Second, the ultrasonic bath aided mixing the $\mathrm{CsCl}$ solution and residues.

Next, we centrifuged the samples at $2500 \mathrm{rpm}$ for $8 \mathrm{~min}$ during the first phase of the flotation. Starches have an average specific gravity of $1.5 \mathrm{~g} / \mathrm{cm}^{3}$ and this phase isolates them from other particles not of interest for this analysis (Banks and Greenwood 1975). We then decanted the supernatant into new vials that each had ultrapurified water added and initiated the $\mathrm{CsCl}$ solution being diluted. The second phase of the flotation procedure consisted of us centrifuging the vials at $9000 \mathrm{rpm}$ for $8 \mathrm{~min}$. During this phase, any possible starches began to move down in the vials. We repeated this second phase two more times but operated the centrifuge for 5 min each dilution cycle. Between each cycle, we decanted the supernatant and added ultrapurified water, which reduced the specific gravity of the $\mathrm{CsCl}$ solution and forced any starches to the bottoms of the vials. After the last cycle, we added no water; instead, we added a small drop of glycerol $(\sim 0.1 \mathrm{ml})$. Next, we slide mounted and microscopically observed the remaining residue and glycerol solution with a cross-polarized Leica DM2700 P at 400×. Finally, we counted starches, described, photographed them, and then compared them to the reverence collection established by Dr. Pagán-Jiménez.

\section{Taxonomic Identification of the Recovered Starch Grains}

To aid in taxonomic ascription, our reference collection contains modern starches from 140 individual specimens representing 70 genera and 63 wild, domesticated, and cultivated species from the Antilles, continental tropical Americas primarily the insular Caribbean, and parts of the Old World. Ciofalo added specimens purchased at local Caribbean markets and collected from the wild in The Bahamas, as well as from the Economic Botany collection of Naturalis Biodiversity Center Leiden, The Netherlands. We first located starches under polarized and color filtered view. The color filter reduced background "noise" (other birefringent particles) and made most starches appear with light purple and yellow hues (even if they were damaged) alternating amongst the triangular areas of the starch that were manifested by the extinction cross. A starch extinction cross is an indicative element, but not exclusive, which differentiate starches from many other particles. When we detected a starch, we photographed it multiple times with both polarized filters and bright field view (normal transmitted light). Importantly for taxonomic identification, we photographed each starch with different focal lengths and rotated them when possible.

After we observed, photographed, and described the recovered starches, we compared them to our modern reference collection and published sources (Cagnato and Ponce 2017; Dickau 2005; Dickau et al. 2012; Holst et al. 2007; Horrocks and Rechtman 2009; Mickleburgh and Pagán-Jiménez 2012; Musaubach et al. 2013; Pagán-Jiménez 2007, 2015a; Pagán-Jiménez et al. 2016; Pagán-Jiménez et al. 2015; Pearsall et al. 2004; Perry et al. 2007; Piperno and Dillehay 2008; Piperno and Holst 1998; Piperno et al. 2000; Piperno et al. 2009; Reichert 1913; Zarrillo 2012; Zarrillo 
et al. 2008). We identified starch grains to the lowest taxonomic level when possible. The morphometric features employed for identification were size, shape, border, facets, lamellae, fissure, hilum type, and extinction cross arms morphology. When a starch's diagnostic characteristics were obscured or absent, either category not identified or $c f$. was used, the latter in reference to the closest tentative identification. Thus, we based both secure and tentatively identified starches on diagnostic features.

In addition to taxonomic diagnostic characteristics, we observed and recorded damage to the starches likely caused by culinary practices. We compared these described damage characteristics to experimental studies, which aided with interpretations of the likely causes of damage to the recovered starches (Babot 2003, 2006; Barton 2007; Beck and Torrence 2006; Delwen 2006; Gomez et al. 1992; Gomez et al. 1991; Henry et al. 2009; Lamb and Loy 2005; Logan et al. 2012; Mickleburgh and Pagán-Jiménez 2012; Pagán-Jiménez 2015b; Pagán-Jiménez et al. 2017; Piperno et al. 2004; Vinton et al. 2009; Wang et al. 2017). The damage caused to the starches was another line of evidence for us, demonstrating how culinary practices emerged in this data set.

\section{Results}

Table 2 provides the summary of results obtained from the samples investigated for starch content. The highest success rate we obtained $(73 \%)$ for the extraction of starches from El Flaco griddle samples is found in Table 2. While both La Luperona and Palmetto Junction had significant success rates of starch recovery (60\%), Palmetto Junction had a larger average number of individual starches per sample (3) compared with El Flaco (1.5) or La Luperona (1). Fewer starches recovered per sample could be due to many factors including the frequency that griddles were used, anthropogenic mechanical damage due to food processing and cooking, or taphonomic reasons (organic or chemical degradation) (Barton 2009; Hutschenreuther et al. 2017; PagánJiménez 2008; Rodríguez Suárez and Pagán-Jiménez 2008). However, there was a negligible difference of porosity or other negative surfaces between the samples in this study from the Dominican Republic compared with The Bahamas, which would not influence the greater number of starches, recovered from the Palmetto Junction samples. In addition, another reason we recovered few individual starches from some of the griddles in this study may be due to which foods were processed with the griddles, i.e., terrestrial animals, marine food sources, or non-starchy dietary plants.

Both tuberous and seed plants dominated our assemblage of identified starch grains, which included zamia, manioc, maize, and chili pepper. We securely identified chili pepper from only one sample from La Luperona. We did not identify any remains of either maize or manioc from La Luperona, whereas Palmetto Junction's most ubiquitous plant remains securely identified by us were from manioc (27\%). The most commonly recovered evidence (ubiquity) of cultivars from the entire artifact assemblage was from manioc and maize plant remains. Ubiquity refers to the occurrence of identified plant taxa amongst the entire artifact sample spectra (Hubbard 1980). It is important to remember that interpretations based on ubiquity analyses are limited by both the sample size and preservation (Kadane 1988); with 45 artifacts sampled from three archaeological sites, these limitations have been likely marginalized. However, we do not believe 
Table 3 Identified taxa per sample and the number of individual starches observed

\begin{tabular}{|c|c|c|c|c|c|c|c|c|c|c|c|c|c|c|c|c|c|c|}
\hline \multicolumn{19}{|c|}{ EI Flaco } \\
\hline Lab ID & N & 岁 & 山্口 & لু & \begin{tabular}{l}
$W^{\prime}$ \\
\hdashline
\end{tabular} & $\stackrel{\circ}{0}$ & $\frac{a}{N}$ & $\frac{a}{\omega}$ & 亗 & 岕 & 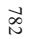 & $\underset{\infty}{\infty}$ & ত্ర & ఫొ & త్ర & & & \\
\hline Sample type & $\hat{\overbrace{}}$ & $\hat{\Omega}$ & 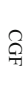 & 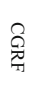 & $\hat{\Omega}$ & ڤิ & $\hat{\Omega}$ & $\hat{\Omega}$ & $\widehat{\Omega}$ & $\hat{\Omega}$ & $\hat{\Omega}$ & $\hat{\Omega}$ & $\hat{\Omega}$ & $\stackrel{\Omega}{\pi}$ & $\widehat{\Omega}$ & 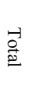 & 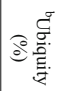 & 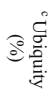 \\
\hline Zamia spp. & & & & 1 & & & & & & & & & & & & 1 & 7 & 7 \\
\hline $\begin{array}{l}\text { Manihot } \\
\text { esculenta }\end{array}$ & & & & & & & & & & & & & & & 2 & 2 & 7 & 7 \\
\hline $\begin{array}{c}\text { cf. } \\
\text { Zingiberaceae }\end{array}$ & & 1 & & & & & & & & & & & & & & 1 & 7 & 7 \\
\hline Zea mays & & & & & & & & 2 & & & & & & & & 2 & 7 & 33 \\
\hline cf. Zea mays & & & & & & & 1 & & & & & 1 & 1 & & 1 & 4 & 27 & -- \\
\hline Unidentified & & & 1 & 1 & 1 & 1 & 2 & & & & 4 & & 1 & & 3 & 14 & -- & -- \\
\hline $\begin{array}{c}\text { Individual } \\
\text { Starches }\end{array}$ & 0 & 1 & 1 & 2 & 1 & 1 & 3 & 1 & 0 & 0 & 4 & 1 & 2 & 0 & 6 & 23 & -- & -- \\
\hline $\begin{array}{c}{ }^{d} \text { Minimum } \\
\text { species } \\
\text { richness }\end{array}$ & 0 & 1 & 1 & 1 & 1 & 1 & 1 & 1 & 0 & 0 & 1 & 1 & 1 & 0 & 2 & -- & -- & -- \\
\hline \multicolumn{19}{|c|}{ La Luperona } \\
\hline Lab ID & - & N & $w$ & + & un & $a$ & $\infty$ & ఠ & $=$ & $\bar{\omega}$ & $\vec{\Phi}$ & $\vec{u}$ & $\Xi$ & $\infty$ & $\varpi$ & & & \\
\hline Sample type & $\hat{\mathrm{T}}$ & $\widehat{\Omega}$ & 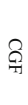 & $\hat{\bigcap}$ & $\hat{\overbrace{}}$ & กิ & $\widehat{\Omega}$ & $\stackrel{\Omega}{0}$ & $\hat{\bigcap}$ & ڤิ & ڤิ & $\hat{\Omega}$ & $\hat{\Omega}$ & $\widehat{\bigcap}$ & $\stackrel{\Omega}{\Omega}$ & $\stackrel{\overrightarrow{0}}{\stackrel{0}{\Xi}}$ & 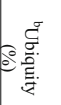 & ङे \\
\hline Zamia spp. & & & & & & & & & & & & 1 & & & 1 & 2 & 13 & 27 \\
\hline cf. Zamia spp. & & & & & & & & 2 & & & 1 & 2 & & & & 5 & 20 & -- \\
\hline $\begin{array}{c}\text { cf. } \\
\text { Xanthosoma } \\
\text { sagittifolium }\end{array}$ & & & & & & & & 2 & & & & & & & & 2 & 7 & 7 \\
\hline Capsicum spp. & & & & & & & & & & & & 1 & & & & 1 & 7 & 7 \\
\hline Unidentified & & & 2 & & 2 & 1 & 1 & $\begin{array}{c}3+ \\
3+\mathrm{a} \\
{ }^{\mathrm{a}} \mathrm{CL} \\
\sim 26\end{array}$ & 1 & & & & & & & 10 & -- & -- \\
\hline $\begin{array}{c}\text { Individual } \\
\text { Starches }\end{array}$ & 0 & 0 & 2 & 0 & 2 & 1 & 1 & 7 & 1 & 0 & 1 & 3 & 0 & 0 & 1 & 19 & -- & -- \\
\hline $\begin{array}{c}{ }^{\mathrm{d}} \text { Minimum } \\
\text { species } \\
\text { richness }\end{array}$ & 0 & 0 & 0 & 0 & 0 & 1 & 1 & 2 & 0 & 0 & 1 & 2 & 0 & 0 & 1 & -- & -- & -- \\
\hline \multicolumn{19}{|c|}{ Palmetto Junction } \\
\hline Lab ID & 定 & 定 & $\ddot{\perp}$ & ¿ & ळু & $\overrightarrow{\mathrm{j}}$ & $\vec{\infty}_{\infty}$ & $\bar{J}$ & $\underset{\infty}{\bar{\infty}}$ & $\bar{\Xi}$ & $\vec{\omega}$ & $\underset{N}{\tilde{N}}$ & $\underset{\omega}{\omega}$ & $\vec{\sigma}$ & $\underset{\infty}{\vec{\infty}}$ & & & \\
\hline Sample type & $\hat{\mathrm{T}}$ & $\hat{\Omega}$ & १ి & $\hat{\imath}$ & ڤิ & คิ & ڤิ & ڤิ & $\hat{\mathrm{T}}$ & $\hat{\mathrm{T}}$ & 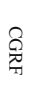 & กิ & $\hat{\bigcap}$ & 尺ి & 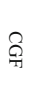 & $\stackrel{\vec{\circ}}{\ddot{E}}$ & อ气 & ङ \\
\hline Zamia spp. & & & & & & & & & & & 1 & & & & & 1 & 7 & 13 \\
\hline cf. Zamia spp. & & & & & & & & & & 1 & & & & & & 1 & 7 & -- \\
\hline $\begin{array}{l}\text { Manihot } \\
\text { esculenta }\end{array}$ & 21 & 1 & 1 & & & & & & & 1 & & & & & & 24 & 27 & 40 \\
\hline $\begin{array}{l}\text { cf. Manihot } \\
\text { esculenta }\end{array}$ & $\begin{array}{c}2+ \\
{ }^{\mathrm{a}} \mathrm{CL} \\
\sim 300\end{array}$ & & 2 & & 1 & & & 1 & & & & & & & & 6 & 27 & -- \\
\hline Zea mays & & & & & & & & & & & & & & & 1 & 1 & 7 & 20 \\
\hline cf. Zea mays & & & 1 & & & & & & & & 1 & & & & & 2 & 13 & -- \\
\hline Unidentified & 7 & 1 & 2 & & & & & & & & & & 1 & & & 11 & -- & -- \\
\hline $\begin{array}{c}\text { Individual } \\
\text { Starches }\end{array}$ & 30 & 2 & 6 & 0 & 1 & 0 & 0 & 1 & 0 & 2 & 2 & 0 & 1 & 0 & 1 & 46 & -- & -- \\
\hline $\begin{array}{c}{ }^{d} \text { Minimum } \\
\text { species } \\
\text { richness }\end{array}$ & 1 & 1 & 2 & 0 & 1 & 0 & 0 & 1 & 0 & 2 & 2 & 0 & 1 & 0 & 1 & & -- & -- \\
\hline
\end{tabular}

$C G F$ clay griddle fragment, $C G R F$ clay griddle rim fragment, $C L$ starch cluster

${ }^{a}$ Clusters are not included in the individual starch totals, because the precise number of starches in the clusters could not be determined

${ }^{\mathrm{b}}$ Ubiquity was calculated by dividing the presence of identified taxa by the total number of analyzed artifacts per site

${ }^{\mathrm{c}}$ Ubiquity was calculated by dividing the presence of both securely and tentatively identified taxa by the total number of analyzed artifacts per site

dMinimum species richness combined both tentative ("cf.") and secure identifications, which excluded starches that were not identified because they could have been produced by some of the already identified taxa 
these ubiquity measures suggest or indicate the identified plant's contributions to overall diet, instead it may suggest contributions to starchy culinary practices.

From the Dominican Republic archaeological sites, the samples allowed us to identify other domestic and possibly wild taxa that included maize, chili pepper, and zamia. Due to the identification of maize starch grains amongst the sample spectra, El Flaco griddle use incorporated the production of maize into food derivatives (Table 3). El Flaco griddle samples also demonstrated evidence for manioc, zamia, and $c f$. Zingiberaceae. The latter of which was represented by one starch that measured $53 \mu \mathrm{m} \times 19.1 \mu \mathrm{m}$ and was oblong in shape, convex on both the distal and proximal ends. When we compared the $c f$. Zingiberaceae starch to our modern reference collection and published sources, this starch appeared significantly damaged, encrusted in particles, and would not rotate which left its taxonomic identification at the family level (Pagán-Jiménez et al. 2015). Sample 613 from El Flaco had evidence of maize (Fig. 3A), which measured $17.8 \mu \mathrm{m} \times 15.1 \mu \mathrm{m}$, and was pentagonal in shape with a prominent double border. In addition, this maize starch had a dark central depression that is not found in our reference collection of unmodified starches. Sample 788 from El Flaco had evidence of a $c f$. maize starch (Fig. 3B), which measured $22.4 \mu \mathrm{m} \times$ $19.4 \mu \mathrm{m}$, and had a faint but noticeable double border. This $c f$. maize starch had asymmetrical striations near the lineal fissure and most of the starch was encrusted in particles. Sample 797 from El Flaco had both manioc and $c f$. maize recovered, suggesting this griddle helped process multiple types of edible plants.

La Luperona griddles had zamia recovered as the most ubiquitous type of starchy plant remains identified (Table 3). La Luperona griddle use reflected patterns of other griddles studied from Caribbean archaeological contexts, which included being used to process multiple species of plants and the absence of manioc (Pagán-Jiménez 2008, 2010; Rodríguez Suárez and Pagán-Jiménez 2008). In our comparison of griddle use, La Luperona was the exception for an absence of both manioc and maize identified from the analyzed griddle assemblage. Sample 15 from La Luperona had evidence of a chili pepper starch (Fig. 3K), which measured $22.6 \mu \mathrm{m} \times 21.6 \mu \mathrm{m}$, and was circular in shape, but oval when rotated with a prominent lineal fissure (Fig. 3K1). Sample 15 also had evidence of a zamia starch (Fig. 3M), which measured $41.83 \mu \mathrm{m} \times 34.66 \mu \mathrm{m}$, with pronounced concentric lamellae, and was circular in shape, but oval in shape with an apparent false lineal fissure when rotated (Fig. 3M1). This zamia starch's false lineal fissure is noticeably different from the chili pepper lineal fissure. The false lineal fissure is likely a visual artifact from the compression of the lamellae. The size of the starch, shape of the lamellae, and compression facet helped us to confirm the identification of this zamia starch grain (Fig. 3M, M1). Sample 10 had evidence of two $c f$. cocoyam starches, which had longest measurements of $10.15 \mu \mathrm{m}$ and $8.14 \mu \mathrm{m}$ respectively, both were bell shaped with at least two basal facets. Because they were unable to be rotated, their taxonomic identification was left tentative. Both sample 15 and sample 10 provided us with evidence for multiple species of plants being prepared.

The Palmetto Junction griddle assemblage provided us evidence for the use of manioc, maize, and zamia. Sample 102 from Palmetto Junction had the most starches recovered of all samples. We recovered 30 individual starches and securely identified 21 manioc starch grains. Seven starches were unable to be identified. From sample 102, there are examples displayed (Fig. 3G, H, and I) of securely identified manioc starches determined based on their size $(\mathrm{G}-17.9 \mu \mathrm{m} \times 16.9 \mu \mathrm{m}, \mathrm{H}-12.4 \mu \mathrm{m} \times 11.9 \mu \mathrm{m}, \mathrm{I}-22.5 \mu \mathrm{m} \times 20.3 \mu \mathrm{m}$, shape 
Table 4 Percentages of recovered individual starches with damage patterns from cooking processes. Humid heat and dry heat are in reference to what the cooking environments most likely were to create the starch damage patterns observed

\begin{tabular}{lclllll}
\hline & Humid heat & Dry heat & Heat & Pressure & Enzymatic & Undamaged \\
\hline El Flaco & 17 & 35 & 52 & 26 & 13 & 26 \\
La Luperona & 5 & 16 & 21 & 42 & 5 & 37 \\
Palmetto Junction & 11 & 11 & 21 & 24 & 9 & 52 \\
\hline
\end{tabular}

(truncated bell shaped), amount of compression facets (2-4), and constricted areas (look pinched). In one example, from these three manioc starches (Fig. 3I), a diagnostic stellate fissure was visible. All of the previously listed descriptions fit diagnostic characteristics of bell-shaped manioc starches of our reference collection and published sources (Cagnato and Ponce 2017; Ciofalo et al. 2018; Pagán-Jiménez 2015a:68, 69; Piperno 2006:68). In addition, from sample 102, there was a cluster of approximately 300 starches, with some exposed starches with visible diagnostic characteristics of manioc (Fig. 3L). This cluster of starches was also partially covered with organic material, possibly plant tissue such as cellulose or proteins. Because these starches were partially obscured, part of a cluster, and not able to be rotated, we identified them as $c f$. manioc, but we left them out of the total individual starch count (Table 3).

Of the griddles that had recovered starches, El Flaco had $64 \%$ with evidence containing at least one starch that had damage due to heat (Table 4). La Luperona had $88 \%$ of the griddles with evidence of at least one starch damaged by pressure (Table 4). Palmetto Junction had $67 \%$ of the griddles with evidence of at least one starch damaged by pressure (Table 4). From the entire assemblage of recovered individual starches, $34 \%$ displayed alterations of their characteristics consistent with patterns of damage due to heat, $28 \%$ had damage signs attributed to pressure, and $9 \%$ had damage patterns indicating enzymatic degradation occurred (Henry et al. 2009; Pagán-Jiménez et al. 2017; Vinton et al. 2009; Wang et al. 2017). Of the individual starches we recovered from El Flaco, 52\% were damaged by heat, $26 \%$ by pressure, and $13 \%$ by enzymatic activity. Of the individual starches we recovered from La Luperona, $21 \%$ were damaged by heat, $42 \%$ by pressure, and $5 \%$ by enzymatic activity. Of the individual starches we recovered from Palmetto Junction $21 \%$ were damaged by heat, $24 \%$ by pressure, and $9 \%$ by enzymatic activity.

\section{Discussion}

Some of the griddle fragments presented evidence of having been exposed to heat. For example, the charred remains area visible in Fig. $2 b$ near the bottom of the left image. From this griddle (Palmetto Junction sample 102), we recovered 30 individual starches and a cluster of more than 300 starches. While we dry scraped the entire used surface of the sherd, it is plausible that some of these starches came from that small cluster of charred remains. The starches were in various states of preservation with evidence of food preparation damage. From sample 102, two of the 21 confirmed manioc starches 

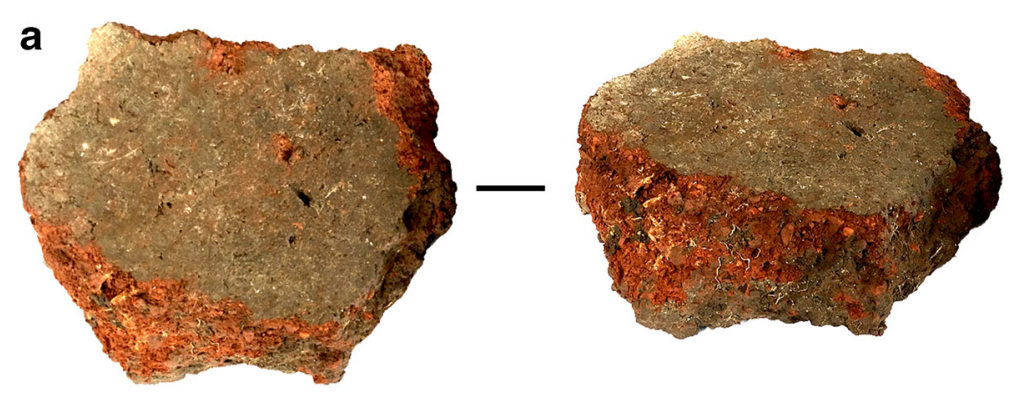

b
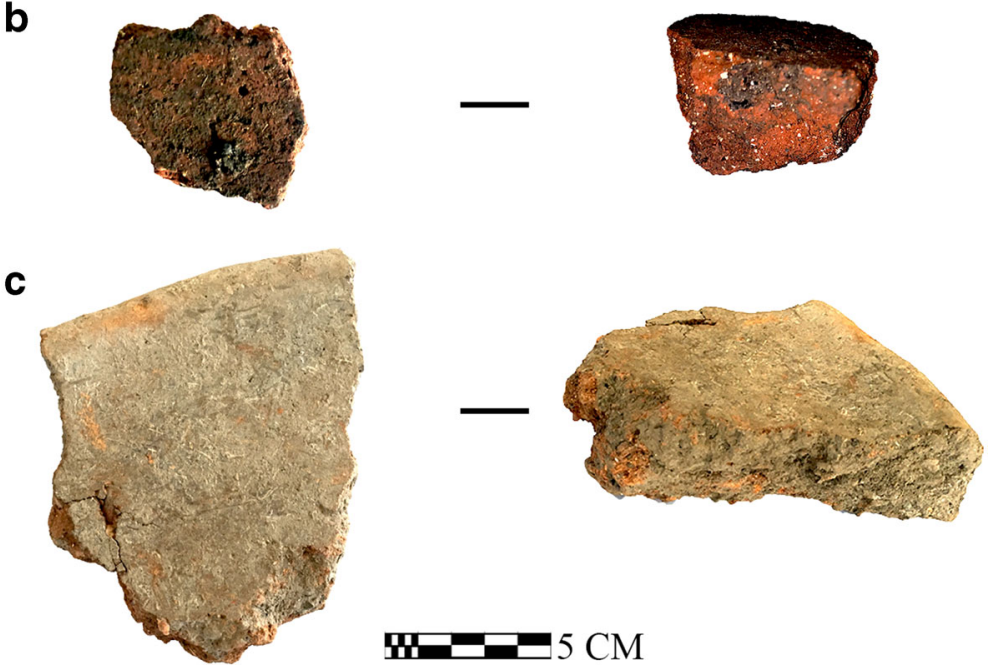

Fig. 2 Three separate clay griddle fragments, one from each site in this study. a El Flaco Sample 585. b Palmetto Junction Sample 102. c La Luperona Sample 4

(Fig. 3G, H), each had evidence of a central depression, which are considered folds created from hot and partially humid cooking environments during the production of manioc-based foods on a griddle (Pagán-Jiménez et al. 2017). The partially humid cooking environments were possibly generated from slightly moist manioc flour.

Many starches we recovered displayed evidence of pressure without noticeable damage from heat (Table 4); a few reasons may explain these differences in starch damage signs and preservation. Clay is a poor thermal conductor; this means griddles heated up slowly and not all starches received intense heat or were completely cooked. Thus, not all starches gelatinized and some are well preserved. For illustration, we microscopically examined pieces of cooked cassava bread (a flatbread made of manioc flour) created by Ciofalo from a modern Haitian recipe (Fig. 4). The recipe included the following steps: (1) manioc tubers were peeled with a metal kitchen knife and grated with a metal grater (which was made from a flattened tin can perforated with the tip of a nail driven through it repeatedly and approximately $0.5 \mathrm{~cm}$ apart to create a rough surface for grating), (2) the mass of the grated manioc was squeezed in a standard dishtowel to remove the majority of liquid, and (3) the remaining mass was placed spread out on a table and left to dry for $6 \mathrm{~h}$. The resulting product was the consistency of moist flour that was formed into circular and flat (1-3-cm thick) layers on a metal 


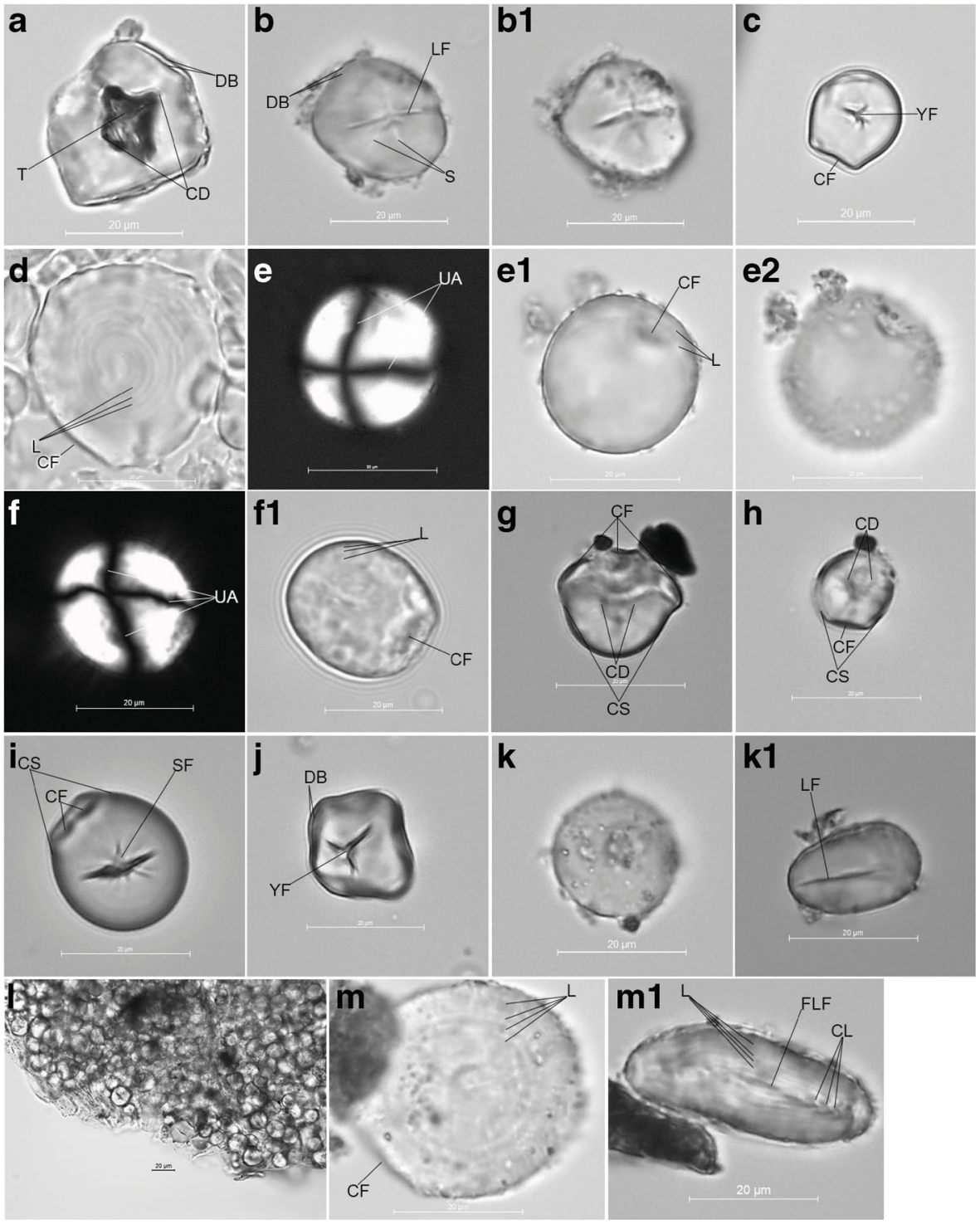

Fig. 3 Examples of starch residues recovered from the 45 sampled griddles. (A) From sample 613, maize starch under bright field view. (B) From sample 788, cf. maize starch under bright field view. (B1) From sample 788, the same cf. maize starch under bright field view at a different focal length. (C) From sample 797, manioc starch under bright field view. (D) From sample 10, cf. zamia starch under bright field view. (E) From sample 15, cf. zamia starch under polarized light and dark field view. (E1) From sample 15, the same cf. zamia starch under bright field view. (E2) From sample 15, the same cf. zamia starch under bright field view at a different focal length. (F) From sample 19, zamia starch under polarized light and dark field view. (F1) From sample 19, the same zamia starch under bright field view. (G) From sample 102, manioc starch under bright field view. (H) From sample 102, manioc starch under bright field view. (I) From sample 102, manioc starch under bright field view. (J) From sample 138, maize starch under bright field view. (K) From sample 15, chili pepper starch under bright field view. (K1) From sample 15, the same chili pepper starch under bright field view but rotated. (L) From sample 102, cluster of cf. manioc starches under bright field view. (M) From sample 15, Zamia spp. starch under bright field view. (M1) From sample 15, the same Zamia spp. starch under bright field view but rotated. Scale bar $=20 \mu \mathrm{m}$. Figure legend: CD central depression, CF compression facet, CL compressed lamellae, CS constricted area, DB double border, FLF false lineal fissure, L lamellae, LF lineal fissure, S striation, SF stellate fissure, T toasting damage, UA undulating extinction cross arm, YF Y-shaped fissure 


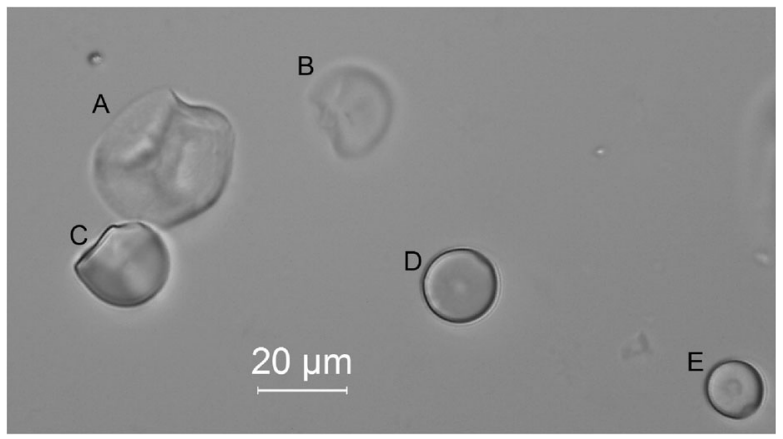

Fig. 4 Modern starches under bright field view, obtained from cassava flatbread prepared by Ciofalo (A) Significantly gelatinized manioc starch. (B) Significantly gelatinized manioc starch (C) Undamaged manioc starch. (D) Undamaged manioc starch. (E) Partially damaged manioc starch from a hot and slightly humid cooking environment

skillet. We cooked this flat bread at approximately $125^{\circ} \mathrm{C}$ for $3-5 \mathrm{~min}$ then flipped it over to cook the other side for the same amount of time.

Once viewed by us under the microscope, a single drop of the sampled cassava bread contained thousands of starches representing different stages of damage, some significantly gelatinized and hundreds undamaged (Fig. 4). Another possibility is that after the griddle was used to cook some food and without being thoroughly washed, its use life was extended by being used as a table for cutting or pounding food or other preparation techniques where heat was not involved (Rodríguez Suárez and PagánJiménez 2008). It is also possible that both the causes of heat and damage were not directly related to use of the griddle and instead occurred earlier in the cooking process, such as roasting manioc and then scraping the skin off with a tool (Ciofalo et al. 2018). Thus, some starches damaged by heat and others damaged only by pressure were preserved on some griddles.

Varieties (cultivars) of manioc are split into two categories of bitter or sweet based on the amount of cyanogenic glucosides (toxins) in the plant (Carneiro 2000). Methods of processing bitter manioc to avoid cyanide poisoning can include boiling, fermenting, or roasting, but more typically tubers are grated and the poisonous juice is squeezed out of the manioc mass (Elias et al. 2000; Flibert et al. 2016; Pagán-Jiménez 2011a). Currently, in Dominican Republic and Turks \& Caicos, both bitter and sweet varieties are grated and squeezed because that is part of the process to make flour. Once manioc is made into flour and dried, it can be stored longer than unprocessed tubers, which makes manioc flour both an easily preserved food source and a mobile trade good (Lathrap 1973; Sheets et al. 2012). Because neither the sequence of procedures to remove poison from manioc nor the steps needed to create flour are necessarily intuitive, preparation techniques may have traveled with the plant as transferred knowledge (Eerkens and Lipo 2007) to avoid producing poisoned manioc foods and/or creating manioc flour (Blench 2014). Alternatively, other poisonous plants (such as zamia) endemic to both Dominican Republic and the Bahama archipelago may have been processed using similar methods to manioc. Therefore, the procedures to remove poison from manioc may have been locally developed for zamia and then applied to manioc when it was introduced, which would have been the addition of another tuberous plant to a preexisting cultural repertoire needing similar food processing technologies (Leach 1999). 
Supposed "manioc-only artifacts" consistently have had a broad suite of plant species identified from their microbotanical remains (Berman and Pearsall 2008; Pagán-Jiménez 2008, 2009, 2013; Perry 2002, 2005; Rodríguez Suárez and Pagán-Jiménez 2008). From our analysis, the majority of griddles $(60 \%)$ that had manioc recovered from their surfaces also had residues of other plants species recovered and identified; this is empirical evidence that invalidates earlier preconceptions of definitive tool types associated with manioc use (see other disscusions on this in DeBoer 1975; Perry 2002, 2005). The ancient starch data we recovered during this study indicate archaeobotanical data are (again) a more reliable source for assessing the plants processed with these tools than are early European written documents. Including tentatively identified starches, our study recovered identified manioc starch from seven out of 45 sampled griddles (Table 3). Adding the data from our study, to griddles from the Greater Caribbean region analyzed for starch content that demonstrated evidence of manioc, the new total is now 12 out of 76 griddles (McKey et al. 2010; Pagán-Jiménez in Oliver 2014; PagánJiménez in Ulloa Hung 2014:115,138; Pagán-Jiménez 2008, 2009, 2011a, b, 2012; Rodríguez Suárez and Pagán-Jiménez 2008; van den Bel et al. 2013).

Sample 613 from El Flaco had evidence of a maize starch grain (Fig. 3A), which was likely toasted in a similar fashion for the creation of tostado (toasted maize kernels with a little water) (Babot 2006). Sample 788 from El Flaco had evidence of $c f$. maize that was altered by light pressure (such as scraping or grating) determined from the asymmetrical central striations. The maize kernel that produced this starch was also cooked in a dry cooking environment, but likely completely dry, evinced from the encrustation of particles on the surface of the starch. Likewise, sample 15 from La Luperona provided us evidence of $c f$. zamia (Fig. 3E2) and chili pepper (Fig. 3K) starches encrusted with particles, suggesting they were prepared in dry cooking environments as well. We are not sure what the particles are made from that cover the surface of starches that were cooked in dry cooking environments, but it is possible they were parts of other less-resistant starches that were broken apart during the cooking process (Henry et al. 2009). Regarding the ubiquity of maize starch remains recovered from El Flaco and Palmetto Junction griddles, La Luperona appears as an outlier. It is possible that maize was prepared in different ways at La Luperona instead of on griddles. Studies involving other food preparation tools from all three sites are ongoing by Ciofalo, and at El Flaco, macrobotanical and other microbotanical studies (phytoliths and starches) are currently being carried out by Dr. Jaime Pagán-Jiménez, so this picture may change in the light of new evidence.

The potential foodways ranks based on the data generated from our study do not intend to influence interpretations of contributions to overall diet, instead potential foodways ranks is a possible crescendo for discussions and interpretations of ubiquity measures, but only a hint of possible culinary preferences regarding starchy plants prepared on these griddles (Pearsall 2018:66). Maize, as the most ubiquitous plant remains we identified from the analyzed residues from El Flaco, suggests that many of their households had access to maize, and perhaps maize was the preferred or most valued plant ingredient for their culinary practices with these griddles, contributing to its potential foodways rank (Table 5). La Luperona inhabitants prepared zamia-based foods on griddles, and Palmetto Junction occupants prepared recipes incorporating manioc on griddles, which may suggest starchy foodways ranks or preferred culinary practices (Table 5). Maize has been one of the most ubiquitous plant residues recovered 
Table 5 Potential foodways rank based on ubiquity measures of sampled artifacts, where 1 is the most likely to have contributed to plant-based foods prepared on these griddles

\begin{tabular}{llll}
\hline Archaeological site & El Flaco & La Luperona & Palmetto Junction \\
\hline Zamia spp. & 2 & 1 & 3 \\
Manihot esculenta & 2 & & 1 \\
Zea mays & 1 & & 2 \\
Capsicum spp. & & 2 & \\
\hline
\end{tabular}

from Greater Antilles archaeological contexts, and thus, most households likely had access to foods created from maize (Chinique de Armas et al. 2015; Mickleburgh and Pagán-Jiménez 2012; Pagán-Jiménez 2007, 2010; Pagán-Jiménez and Oliver 2008; Rodríguez Suárez and Pagán-Jiménez 2008). However, maize was not native to the Greater Antilles nor to the Bahama archipelago and required human assistance to be propagated (Doebley 2004; Liogier 1978; Newsom 2006; Tian et al. 2009). Therefore, we add additional evidence from our study and agree with the interpretation that maize was a part of the transported landscape brought to these islands (Berman and Pearsall 2008; Rodríguez Ramos 2011; Rodríguez Ramos et al. 2013b). The maize starch grains we recovered from these griddles supports the idea that kernels were removed from the cob (peduncle) and altered by grinding, pounding, or toasting which would be culinary practices absent from European written sources for the Greater Antilles (Fernández de Oviedo 1959 [1526]; Las Casas 1876 [1561], 1909; Pané 1999 [1571]).

These results provided us with some insights into the studied areas constructed cultural niches involving clay griddles and associated adaptation strategies, which likely involved the translocation of exogenous plants, and the culinary practices involved to manipulate those plants to produce edible food sources. The identified plants and interpreted foodways have been placed in the described geographical and chronological contexts. A combined phytocultural system can be suggested for this area of the northern Caribbean, which includes (1) the development of "conucos" house gardens (for the production of manioc, possibly together with maize and other fruit and spicy plants such as chili pepper); it was these gardens where experimentation and cultural acceptance of exotic plants conceivably occurred before being integrated as a significant culinary source (Boivin et al. 2012); (2) the use of open plots (for the production of maize and manioc which are efficient in sunny areas); (3) tropical dry forest management (for the procurement or production of zamia); and (4) the use of clay griddles for the production of a broad suite of plant-based foods. Similar phytocultural scenarios have been suggested for human groups from the Greater Antilles from the Early Ceramic Age (400 BCE-800 CE) (Pagán-Jiménez 2007; Rodríguez Suárez and Pagán-Jiménez 2008). From our study, we have added a line of evidence for similar phytocultural systems during the Late Precolonial period in both the Dominican Republic and the southern Bahama archipelago. While for griddles the ubiquitous prepared plant complex at El Flaco (zamia, maize, manioc) varied from La Luperona (zamia, chili pepper), it does not appear to have major new additions at Palmetto Junction (zamia, maize, manioc), but the preferences, values, or supply of manioc appears to have been different at Palmetto Junction. For this investigation, we took an approach to foodways using cultural niche construction theory to interpret phytocultural dynamics in local (site level), microregional (northwestern Dominican Republic), and macroregional contexts (northern Caribbean). 
We have reconstructed culinary practices and cultural niches at different geographic scales. It is evident that at El Flaco zamia, maize, manioc, and a plant from Zingiberaceae were prepared on griddles. At La Luperona, the community perhaps did not use or favor manioc and maize but incorporated zamia, chili pepper perhaps as a condiment, and possibly cocoyam into their culinary repertoire. Palmetto Junction seemingly had culinary practices similar to El Flaco by preparing zamia, maize, and manioc on griddles. Through adding microbotanical evidence to a growing database of dietary plants processed in the northern Caribbean, archaeologists are illustrating a diverse spectrum of starchy foodways (Berman and Pearsall 2000, 2008; Chinique de Armas et al. 2015; Pagán-Jiménez 2010; Rodríguez Suárez and Pagán-Jiménez 2008).

Reinforced culinary practices require cultural information to be transmitted as well as biological foundations of mental and physical facilities to harvest, process, cook, and consume the food (O'Brien et al. 2010). Once transmitted, dietary practices serve as units of replication that can be inherited and modified as part of a cultural repertoire (Eerkens and Lipo 2005; Smith 2013). Through different forms of management, plant procurement, and food preparation, humans create their desired niches (Zeder 2015). Interpretations from our data offer explanations regarding how cultural niches were constructed, i.e., how and which plants were prepared on griddles. Cultural niche construction theory offers a perspective on why these niches were constructed, i.e., to reproduce successful foodways that were preferred and offered modes of stability in dynamic environments.

It should be stressed that precolonial human impacts on zamia, maize, and manioc have never been suitably assessed in this case study area. However, the idea that Caribbean Indigenous Peoples might have served as dispersal agents for zamia, maize, and manioc into the northern Caribbean cannot be excluded. The translocation of objects, ideas, and plants previously integrated into a system of preferences and values could have aided in overcoming unfamiliar encounters with new places by making new areas more humanized and creating consistent supplies of food vis-à-vis transported landscapes (Anderson 1967; Berman and Pearsall 2008; Pagán-Jiménez 2013; Rodríguez Ramos et al. 2013a). Routinized daily practices can minimize feelings of uncertainty by increasing predictability and familiarity (Berman and Pearsall 2008; Bourdieu 1977:8; Pagán-Jiménez et al. 2019). Communities that used culinary practices involving particular plants could have occurred for more reasons than personal preferences or familiarity; they could also have prepared these products for purposes of exchange for strengthening and maintaining relationships with other communities (Dietler 2007; Hofman and van Duijvenbode 2011). These exchanges could have provided supplementary resources needed for other niches such as access to marine food sources.

\section{Final Remarks}

Our main points are exemplified by the similarities between El Flaco and Palmetto Junction phytocultural strategies, where manioc and maize were most preferred, valued, or used for production of foods with griddles. We expected these similarities of plantbased foods prepared on griddles between El Flaco and La Luperona, because there is evidence of trade or communication between these sites. However, from our study, the culturally constructed niches appear more contrasting between neighboring habitations 
(El Flaco compared with La Luperona) than between sites from neighboring islands (El Flaco and La Luperona combined and compared with Palmetto Junction).

In our study, we used the concept of cultural niche construction to interpret the ancient starch remains, illuminate a partial view of phytocultural repertoires, and explicate variations of identified culinary practices at three precolonial habitations in the northern Caribbean. The evidence suggests that each site had a different use or preference of plantbased food production on griddles. The plant ingredient that all three sites had in common was zamia, which may be reflective of wild abundance of this plant in the past, or mobility and exchange with other areas where zamia was available. In addition, all three sites prepared dietary plants on clay griddles. We suspect this routinized daily practice created a sense of familiarity even with different foods being prepared on the griddles. The particular plants processed on the griddles were successful culinary practices, which were imbedded within the lifeways of these Caribbean Indigenous Peoples.

Earlier preconceptions viewed the griddle as exclusively entangled with the production of cassava flatbread in the Caribbean (see DeBoer 1975; Rouse 1992; Wilson 2007). Other starch analyses of Caribbean griddles indicated their use in preparing a broad suite of dietary plants but not manioc (Pagán-Jiménez in Ulloa Hung 2014:115,138; Pagán-Jiménez 2008, 2009, 2011a; Rodríguez Suárez and PagánJiménez 2008). The results from our study also demonstrated that a broad suite of vegetal-based foods were prepared on griddles, but at two of the sites, evidently manioc as well. The plant remains we recovered from griddles at El Flaco were different from those at La Luperona where we believe pottery or knowledge of clay preparation were exchanged (Ting et al. 2016). Thus, for the Dominican Republic sites studied here, there ostensibly was a community of practice $^{7}$ for some of the pottery production but distinctive communities of plant preparation that used these griddles. Finally, regarding insular Caribbean clay griddles analyzed for starch content, these are the first reported griddles with recovered manioc starch remains. The more artifacts we analyze, the greater the possibilities are for revealing evidence of dynamic culinary practices.

Acknowledgements We thank both Leiden University and the University of Central Florida for providing support for our work. We are grateful to the Department of Environment and Maritime Affairs (DEMA) on Providenciales, Turks \& Caicos Islands that granted permission to conduct the fieldwork and laboratory analyses. We would like to thank the many participants of excavations in Dominican Republic and Turks \& Caicos Islands. Thanks to Simone Casale and Eduardo Herrera Malatesta for the creation of Fig. 1. Thank you to Joseph Sony Jean for the cassava bread recipe. We also are grateful to the team members of the Faculty of Archaeology, Leiden University, for their insightful comments and suggestions on an earlier draft of this manuscript. Our work carried out with the materials of El Flaco (Dominican Republic) have been performed within the framework of a paramount paleoethnobotanical research designed and carried out by Dr. Jaime Pagán-Jiménez for NEXUS1492. Without Dr. Pagán-Jiménez, our work would not be possible, special thanks to him for his guidance with the starch analysis. Finally, we would like to thank the three anonymous reviewers for their insightful feedback, which made critical changes to the final draft of this manuscript.

Funding Information The results of this study were made possible by the European Research Council, ERC-Synergy NEXUS1492 project grant agreement 319209. Research was also made possible due to a study trip to the Turks \& Caicos Islands through the Leiden University Fund/Byvanck Fonds 76O1/M/1 9.01.2O17/ Bck.

\footnotetext{
$\overline{{ }^{7} \text { See Lave and Wenger (1991:98) }}$ for the basis of how we understand the community of practice concept.
} 
Open Access This article is distributed under the terms of the Creative Commons Attribution 4.0 International License (http://creativecommons.org/licenses/by/4.0/), which permits unrestricted use, distribution, and reproduction in any medium, provided you give appropriate credit to the original author(s) and the source, provide a link to the Creative Commons license, and indicate if changes were made.

\section{References}

Aceituno, F. J., \& Loaiza, N. (2014). Early and Middle Holocene evidence for plant use and cultivation in the Middle Cauca River Basin, Cordillera Central (Colombia). Quaternary Science Reviews, 86, 49-62. https://doi.org/10.1016/j.quascirev.2013.12.013.

Aceituno, F. J., \& Martín, J. G. (2017). Plantas Amerindias En La Mesa De Los Primeros Europeos En Panamá Viejo. Latin American Antiquity, 28(1), 127-143. https://doi.org/10.1017/laq.2016.9.

Allaire, L. (1999). Archaeology of the Caribbean region. In F. Salomon \& S. Schwartz (Eds.), The Cambridge History of the Native Peoples of the Americas, Vol III, part 2: South America. Cambridge: Cambridge University Press.

Anderson, E. (1967). Plants, man and life. Mineola: Dover Publications, Inc.

Appadurai, A. (1981). Gastro-Politics in Hindu South-Asia. American Ethnologist, 8(3), 494-511. https://doi. org/10.1525/ae.1981.8.3.02a00050.

Atchison, J., \& Fullagar, R. (1998). Starch residues on pounding implements from Jinmium rock-shelter. In R. Fullagar (Ed.), A closer look: recent Australian studies of stone tools (Sydney University Archaeological Methods Series) (Vol. 6, pp. 109-126). Sydney: University of Sydney.

Babot, M. D. P. (2003). Starch grain damage as an indicator of food processing. Paper presented at the Phytolith and starch research in the Australian-Pacific-Asian regions : The state of the art. Canberra

Babot, M. D. P. (2006). Damage on starch from processing Andean food plants. In R. Torrence \& H. Barton (Eds.), Ancient starch research (pp. 66-67). Walnut Creek: Left Coast Press Inc..

Banks, W., \& Greenwood, C. T. (1975). Starch and its Components. Edinburgh: Edinburgh University Press.

Barton, H. (2007). Starch residues on museum artefacts: implications for determining tool use. Journal of Archaeological Science, 34(10), 1752-1762. https://doi.org/10.1016/j.jas.2007.01.007.

Barton, H. (2009). cStarch granule taphonomy: the results of a two year field experiment. In M. Haslam, G. Robertson, A. Crowther, S. Nugent, \& L. Kirkwood (Eds.), Archaeological science under a microscope: studies in residue and ancient DNA analysis in honour of Tom Loy (pp. 129-140).

Barton, H., \& Torrence, R. (2015). Cooking up recipes for ancient starch: assessing current methodologies and looking to the future. Journal of Archaeological Science, 56, 194-201. https://doi.org/10.1016/j. jas.2015.02.031.

Barton, H., Torrence, R., \& Fullagar, R. (1998). Clues to stone tool function re-examined: Comparing starch grain frequencies on used and unused obsidian artefacts. Journal of Archaeological Science, 25(12), 1231-1238. https://doi.org/10.1006/jasc.1998.0300.

Beck, W., \& Torrence, R. (2006). Starch pathways. In R. Torrence \& H. Barton (Eds.), Ancient starch research (pp. 53-74). Walnut Creek: Left Coast Press Inc..

Berman, M. J., \& Pearsall, D. M. (2000). Plants, people, and culture in the prehistoric Central Bahamas: a view from the three dog site, an early Lucayan settlement on San Salvador Island, Bahamas. Latin American Antiquity, 11(03), 219-239. https://doi.org/10.2307/972175.

Berman, M. J., \& Pearsall, D. M. (2008). At the crossroads: starch grain and phytolith analyses in Lucayan prehistory. Latin American Antiquity, 19(2), 181-203. https://doi.org/10.2307/25478223.

Berman, M. J., Gnivecki, P. L., \& Pateman, M. P. (2013). The Bahama archipelago. In W. F. Keegan, C. L. Hofman, \& R. Rodríguez Ramos (Eds.), The Oxford handbook of Caribbean archaeology (pp. 264-280). Oxford: Oxford University Press.

Blench, R. (2014). The diffusion of cassava in Africa: lexical and other evidence. unpublished: Circulation draft.

Boivin, N., Fuller, D. Q., \& Crowther, A. (2012). Old World globalization and the Columbian exchange: comparison and contrast. World Archaeology, 44(3), 452-469. https://doi.org/10.1080 /00438243.2012.729404

Bourdieu, P. (1977). Outline of a theory of practice (Vol. 16). Cambridge: Cambridge University Press.

Bourdieu, P. (1979). La distinction: critique sociale du jugement. Paris: Editions de minuit.

Cagnato, C., \& Ponce, J. M. (2017). Ancient Maya manioc (Manihot esculenta Crantz) consumption: Starch grain evidence from late to terminal classic (8th-9th century CE) occupation at La Corona, northwestern 
Petén, Guatemala. Journal of Archaeological Science: Reports, 16, 276-286. https://doi.org/10.1016/j. jasrep.2017.09.035.

Carneiro, R. L. (2000). The evolution of the tipiti. In G. M. Feinman \& L. M. (Eds.), Cultural evolution: contemporary viewpoints (pp. 61-93). New York: Kluwer Academic/Plenum Publishers.

Castilla-Beltrán, A., Hooghiemstra, H., Hoogland, M. L. P., Pagán-Jiménez, J. R., van Geel, B., Field, M. H., et al. (2018). Columbus' footprint in Hispaniola: a paleoenvironmental record of indigenous and colonial impacts on the landscape of the central Cibao Valley, northern Dominican Republic. Anthropocene, 22, 66-80.

Chinique de Armas, Y., Buhay, W. M., Rodríguez Suárez, R., Bestel, S., Smith, D., Mowat, S. D., \& Roksandic, M. (2015). Starch analysis and isotopic evidence of consumption of cultigens among fisher-gatherers in Cuba: the archaeological site of Canímar Abajo, Matanzas. Journal of Archaeological Science, 58, 121-132. https://doi.org/10.1016/j.jas.2015.03.003.

Ciofalo, A. J., Keegan, W. F., Pateman, M. P., Pagán-Jiménez, J. R., \& Hofman, C. L. (2018). Determining precolonial botanical foodways: starch recovery and analysis, Long Island, The Bahamas. Journal of Archaeological Science-Reports, 21, 305-317. https://doi.org/10.1016/j.jasrep.2018.07.022.

Crock, J. G., \& Bartone, R. N. (1998). Archaeology of Trants, Montserrat. Part 4. Flaked stone and stone bead industries. Annals of Carnegie Museum, 67(3), 197-224.

Crouch, M., \& O’Neill, G. (2000). Sustaining identities? Prolegomena for inquiry into contemporary foodways. Social Science Information, 39(1), 181-192.

DeBoer, W. R. (1975). The archaeological evidence for manioc cultivation: a cautionary note. American Antiquity, 40(4), 419-433.

Delwen, S. (2006). Modified starch. In T. Robin \& B. Huw (Eds.), Ancient starch research (pp. 205-216). Walnut Creek: Left Coast Press.

Denevan, W. M. (1992). The pristine myth: the landscape of the Americas in 1492. Annals of the Association of American Geographers, 82(3), 369-385.

Dickau, R. (1999). Paleoethnobotany of the Lake Managua Region, Nicaragua. Master's thesis, University of Calgary.

Dickau, R. (2005). Resource use, crop dispersals, and the transition to agriculture in prehistoric Panama: evidence from starch grains and macroremains. Doctoral dissertation, PhD. Diss., Temple University.

Dickau, R., Ranere, A. J., \& Cooke, R. G. (2007). Starch grain evidence for the preceramic dispersals of maize and root crops into tropical dry and humid forests of Panama. Proceedings of the National Academy of Sciences of the United States of America, 104(9), 3651-3656. https://doi.org/10.1073/pnas.0611605104.

Dickau, R., Bruno, M. C., Iriarte, J., Prumers, H., Betancourt, C. J., Holst, I., et al. (2012). Diversity of cultivars and other plant resources used at habitation sites in the Llanos de Mojos, Beni, Bolivia: evidence from macrobotanical remains, starch grains, and phytoliths. Journal of Archaeological Science, 39(2), 357-370. https://doi.org/10.1016/j.jas.2011.09.021.

Dietler, M. (2007). Culinary encounters: food, identity, and colonialism. In K. Twiss (Ed.), The archaeology of food and identity (Vol. Occasional Paper) (Vol. 34, pp. 218-242). Carbondale: Center for Archaeological Investigations, Southern Illinois University.

Doebley, J. (2004). The genetics of maize evolution. Annual Review of Genetics, 38(1), 37-59. https://doi. org/10.1146/annurev.genet.38.072902.092425.

Downs, J. F., \& Bleibtreu, H. K. (1972). Human variation: an introduction to physical anthropology. In Beverly Hills. California: Glencoe Press.

DuChemin, G. (2005). Animal use and exploitation at palmetto junction, Turks and Caicos Islands. University of Florida, Gainesville, Unpublished Master's thesis.

Dweba, T. P., \& Mearns, M. A. (2011). Conserving indigenous knowledge as the key to the current and future use of traditional vegetables. International Journal of Information Management, 31(6), 564-571. https://doi.org/10.1016/j.ijinfomgt.2011.02.009.

Eerkens, J. W., \& Lipo, C. P. (2005). Cultural transmission, copying errors, and the generation of variation in material culture and the archaeological record. Journal of Anthropological Archaeology, 24(4), 316-334. https://doi.org/10.1016/j.jaa.2005.08.001.

Eerkens, J. W., \& Lipo, C. P. (2007). Cultural transmission theory and the archaeological record: providing context to understanding variation and temporal changes in material culture. Journal of Archaeological Research, 15(3), 239-274. https://doi.org/10.1007/s10814-007-9013-z.

Elias, M., Rival, L., \& McKey, D. (2000). Perception and management of cassava (Manihot esculenta Crantz) diversity among Makushi Amerindians of Guyana (South America). Ethnobiology, 20, 239-265.

Fernández de Oviedo, G. (1851 [1535]). Historia general y natural de las Indias, Islas y Tierra Firme del Mar Océano. Madrid: Real Academia de la Historia. 
Fernández de Oviedo, G. (1959 [1526). Natural history of the West Indies. Chapel Hill: University of North Carolina Press.

Flibert, G., Abel, T., \& Aly, S. (2016). African cassava traditional fermented food: the microorganism's contribution to their nutritional and safety values-a review. International Journal of Current Microbiology and Applied Sciences, 5(10), 664-687. https://doi.org/10.20546/ijcmas.2016.510.074.

Fuente García, S. D. L. (1976). Geografia Dominicana. Santo Domingo: Editorial Colegial Quisqueyana.

Gomez, M. H., Waniska, R. D., \& Rooney, L. W. (1991). Starch characterization of nixtamalized corn flour. Cereal Chemistry, 68(6), 578-582.

Gomez, M. H., Lee, J. K., Mcdonough, C. M., Waniska, R. D., \& Rooney, L. W. (1992). Corn starch changes during tortilla and tortilla Chip processing. Cereal Chemistry, 69(3), 275-279.

González Herrera, U. M. (2016). Food preparation and dietary preferences among the Arawak aboriginal communities. In I. Roksandic (Ed.), Cuban archaeology in the Caribbean (pp. 168-184). Gainesville: Gainesville University Press of Florida.

Haahr, M., \& Haahr, S. (2018). Random.org. https://www.random.org/. Accessed 30 Jul 2018.

Hart, T. C. (2011). Evaluating the usefulness of phytoliths and starch grains found on survey artifacts. Journal of Archaeological Science, 38(12), 3244-3253. https://doi.org/10.1016/j.jas.2011.06.034.

Henry, A. G., Hudson, H. F., \& Piperno, D. R. (2009). Changes in starch grain morphologies from cooking. Journal of Archaeological Science, 36(3), 915-922. https://doi.org/10.1016/j.jas.2008.11.008.

Henry, A. G., Brooks, A. S., \& Piperno, D. R. (2014). Plant foods and the dietary ecology of Neanderthals and early modern humans. Journal of Human Evolution, 69, 44-54. https://doi.org/10.1016/j. jhevol.2013.12.014.

Henry, A. G., Spiteri, C. D., Budel, T., Hutschenreuther, A., Schmidt, S., \& Watzke, J. (2016). Methods to isolate and quantify damaged and gelatinized starch grains. Journal of Archaeological Science-Reports, 10, 142-146. https://doi.org/10.1016/j.jasrep.2016.09.003.

Hofman, C. L., \& Hoogland, M. L. P. (2015). Investigaciones arqueológicas en los sitios El Flaco (Loma de Guayacanes) y La Luperona (Unijica). Informe pre-liminar. Boletín del Museo del Hombre Dominicano, 46(42), 61-74.

Hofman, C. L., \& van Duijvenbode, A. (2011). Communities in contact: essays in archaeology, Ethnohistory \& Ethnography of the Amerindian Circum-Caribbean. Leiden: Sidestone Press.

Hofman, C. L., Ulloa Hung, J., Herrera Malatesta, E., Jean, J. S., Sonnemann, T., \& Hoogland, M. L. P. (2018). Indigenous Caribbean perspectives: archaeologies and legacies of the first colonised region in the New World. Antiquity, 92(361), 200-216. https://doi.org/10.15184/aqy.2017.247.

Holst, I., Moreno, J. E., \& Piperno, D. R. (2007). Identification of teosinte, maize, and Tripsacum in Mesoamerica by using pollen, starch grains, and phytoliths. Proceedings of the National Academy of Sciences of the United States of America, 104(45), 17608-17613. https://doi.org/10.1073 /pnas.0708736104.

Hoogland, M. L. P., \& Hofman, C. L. (1993). Kelbey's ridge 2, a 14th century Taino settlement on Saba, Netherlands Antilles. Analecta Praehistorica Leidensia, 26, 20.

Horrocks, M., \& Rechtman, R. B. (2009). Sweet potato (Ipomoea batatas) and banana (Musa sp.) microfossils in deposits from the Kona Field System, Island of Hawaii. Journal of Archaeological Science, 36(5), 1115-1126. https://doi.org/10.1016/j.jas.2008.12.014.

Hubbard, R. N. L. B. (1980). Development of Agriculture in Europe and the near-East - evidence from quantitative studies. Economic Botany, 34(1), 51-67. https://doi.org/10.1007/Bf02859554.

Hutschenreuther, A., Watzke, J., Schmidt, S., Budel, T., \& Henry, A. G. (2017). Archaeological implications of the digestion of starches by soil bacteria: interaction among starches leads to differential preservation. Journal of Archaeological Science-Reports, 15, 95-108. https://doi.org/10.1016/j.jasrep.2017.07.006.

Jacobson, K. (n.d.). Jeu d'argile: Étude technologique de la céramique de la Caraỉbe du 13e au 16e siècle. unpublished: Leiden University.

Jennings, F. (1975). The invasion of America: Indians, colonialism, and the cant of conquest. Chapel Hill: University of North Carolina Press.

Kadane, J. B. (1988). Possible statistical contributions to paleoethnobotany. In C. A. Hastorf \& V. S. Popper (Eds.), Current paleoethnobotany: analytical methods and cultural interpretations (pp. 206-214). Chicago: University of Chicago Press.

Keegan, W. F. (1996). West Indian archaeology. 2. After Columbus. Journal of Archaeological Research, 4(4), 265-294. https://doi.org/10.1007/bf02229089.

Keegan, W. F. (2000). West Indian archaeology. 3. Ceramic Age. Journal of Archaeological Research, 8(2), $135-167$.

Keegan, W. F. (2007). Taino Indian myth and practice: the arrival of the stranger king. Gainesville: University Press of Florida. 
Keegan, W. F., \& Hofman, C. L. (2017). The Caribbean before Columbus. New York: Oxford University Press.

Keegan, W. F., Maclachlan, M., \& Byrne, B. (1998). Social foundations of Taino Caciques. In E. M. Redmond (Ed.), Chiefdoms and chieftaincy in the Americas (pp. 217-244). Gainesville: University Press of Florida.

Laffoon, J. E., Hoogland, M. L. P., Davies, G. R., \& Hofman, C. L. (2016). Human dietary assessment in the pre-colonial Lesser Antilles: new stable isotope evidence from Lavoutte, Saint Lucia. Journal of Archaeological Science-Reports, 5, 168-180. https://doi.org/10.1016/j.jasrep.2015.11.020.

Laland, K. N., \& O’Brien, M. J. (2010). Niche construction theory and archaeology. Journal of Archaeological Method and Theory, 17(4), 303-322. https://doi.org/10.1007/s10816-010-9096-6.

Lamb, J., \& Loy, T. (2005). Seeing red: the use of Congo Red dye to identify cooked and damaged starch grains in archaeological residues. Journal of Archaeological Science, 32(10), 1433-1440. https://doi. org/10.1016/j.jas.2005.03.020.

Lambert, J. E. (2018). Ecological communities. In W. Trevathan, M. Cartmill, D. L. Dufour, C. S. Larsen, D. H. O'Rourke, K. Rosenberg, et al. (Eds.), The international encyclopedia of biological anthropology. Hoboken: Wiley-Blackwell.

Las Casas, B. D. (1876 [1561]). Historia de las Indias. Madrid: Imprenta de Miguel Ginesta.

Las Casas, B. D. (1909). Apologetica historia de las Indias. Madrid: Bailey-Ballière e Hijos.

Lathrap, D. W. (1973). The antiquity and importance of long-distance trade relationships in the moist tropics of pre-Columbian South America. World Archaeology, 5(2), 170-186.

Lave, J., \& Wenger, E. (1991). Situated learning: legitimate peripheral participation. New York: Cambridge University Press.

Leach, H. M. (1999). Food processing technology: its role in inhibiting or promoting change in staple foods. In C. Gosden \& J. G. Hather (Eds.), The prehistory of food: appetites for change (pp. 127-136). London: Routledge.

LeFebvre, M. J., DuChemin, G., deFrance, S. D., Keegan, W. F., \& Walczesky, K. (2018). Bahamian hutia (Geocapromys ingrahami) in the Lucayan Realm: pre-Columbian exploitation and translocation. Environmental Archaeology, 24(2), 115-131. https://doi.org/10.1080/14614103.2018.1503809.

Liogier, A. H. (1978). La flora de La Española: análisis, origen probable. Santo Domingo: Akad. de Ciencias de la República Dominicana.

Liu, L., Wang, J., Rosenberg, D., Zhao, H., Lengyel, G., \& Nadel, D. (2018). Fermented beverage and food storage in 13,000 y-old stone mortars at Raqefet Cave, Israel: Investigating Natufian ritual feasting. Journal of Archaeological Science: Reports, 21, 783-793. https://doi.org/10.1016/j.jasrep.2018.08.008.

Logan, A. L., Hastorf, C. A., \& Pearsall, D. M. (2012). "Let's drink together": early ceremonial use of maize in the Titicaca Basin. Latin American Antiquity, 23(3), 235-258. https://doi.org/10.7183/10456635.23.3.235.

Loven, S. (1935). Origins of the Tainan culture, West Indies. Göteborg: Elanders.

Ma, Z. K., Zhang, C., Li, Q., Perry, L. D., \& Yang, X. Y. (2017). Understanding the possible contamination of ancient starch residues by adjacent sediments and modern plants in Northern China. Sustainability, 9(5), 752. https://doi.org/10.3390/su9050752.

McKey, D., Rostain, S., Iriarte, J., Glaser, B., Birk, J. J., Holst, I., \& Renard, D. (2010). Pre-Columbian agricultural landscapes, ecosystem engineers, and self-organized patchiness in Amazonia. Proceedings of the National Academy of Sciences of the United States of America, 107(17), 7823-7828. https://doi. org/10.1073/pnas.0908925107.

Mickleburgh, H. L., \& Pagán-Jiménez, J. R. (2012). New insights into the consumption of maize and other food plants in the pre-Columbian Caribbean from starch grains trapped in human dental calculus. Journal of Archaeological Science, 39(7), 2468-2478. https://doi.org/10.1016/j.jas.2012.02.020.

Mickleburgh, H. L., Laffoon, J. E., Pagán-Jiménez, J. R., Mol, A. A. A., Walters, S., Beier, Z. J. M., et al. (2019). Precolonial/early colonial human burials from the site of White Marl, Jamaica: New findings from recent rescue excavations. International Journal of Osteoarchaeology, 29(1), 155-161. https://doi. org/10.1002/oa.2707.

Mintz, S. W. (1985). Sweetness and power: the place of sugar in modern history. New York: Viking.

Montenegro, R. A., \& Stephens, C. (2006). Indigenous health in Latin America and the Caribbean. Lancet, 367(9525), 1859-1869. https://doi.org/10.1016/S0140-6736(06)68808-9.

Morehart, C. T., \& Morell-Hart, S. (2015). Beyond the Ecofact: toward a social paleoethnobotany in Mesoamerica. Journal of Archaeological Method and Theory, 22(2), 483-511. https://doi.org/10.1007 /s10816-013-9183-6.

Morell-Hart, S. (2012). Foodways and resilience under apocalyptic conditions. Culture Agriculture Food and Environment, 34(2), 161-171. https://doi.org/10.1111/j.2153-9561.2012.01075.x. 
Morsink, J. (2012). The power of salt: a holistic approach to salt in the Prehistoric Circum-Caribbean Region. $\mathrm{PhD}$ diss., University of Florida, Gainesville,

Moya Pons, F. (2004). Atlas de los Recursos naturales de la República Dominicana. Santo Domingo: Secretaría de Estado de Medio Ambiente y Recursos Naturales.

Musaubach, M. G., Plos, A., \& Babot, M. D. (2013). Differentiation of archaeological maize (Zea mays L.) from native wild grasses based on starch grain morphology. Cases from Argentina. Journal of Archaeological Science, 40(2), 1186-1193. https://doi.org/10.1016/j.theCentralPampasofjas.2012.09.026.

Newsom, L. A. (1988). Archaeobotanical analysis of three features from a prehistoric habitation site in Puerto Rico: El Fresal, Cuyon, Aibonito. In M. J. Melendez (Ed.), Mitigación Arqueológica Franja del Yacimiento Area B, Barrio Cuyón, Aibonito, Puerto Rico (pp. C1-C13). Washington, D.C.: Department of Agriculture, Programa de Fincas Familiares Titulo VI.

Newsom, L. A. (1991). Paleoethnobotanical analysis of midden remains from the Wanapa site (B-016), Bonaire. In J. B. Haviser (Ed.), The first Bonaireans (pp. 242-262). Curacao: ): Institute of Archaeology and Anthropology.

Newsom, L. A. (1992). Archaeobotanical analysis of flotation samples from site PO-38, Cerrillos River Valley, Puerto Rico. In G. Weaver (Ed.), Phase II archaeological data recover at PO-38, El Parking site, Barrio Maraguez, Ponce,Puerto Rico (p. Appendix C). Jacksonville District: U.S. Army Corps of Egineers.

Newsom, L. A. (1993). Native West Indian Plant Use. dissertation, PhD diss., University of Florida, Gainesville, University Microfilms, Ann Arbor.

Newsom, L. A. (2006). Caribbean maize first farmers to Columbus. In J. Staller, R. Tykot, \& B. Benz (Eds.), Histories of maize in Mesoamerica: multidisciplinary approaches (pp. 325-343). Amsterdam: Academic Press.

Newsom, L. A. (2008). Caribbean paleoethnobotany: present status and new horizons (understanding the evolution of an indigenous ethnobotany). In C. L. Hofman, M. L. P. Hoogland, \& A. L. Van Gijn (Eds.), Crossing the borders: new methods and techniques in the study of archaeological materials from the Caribbean, University of Alabama Press, Tuscaloosa (pp. 173-194). Tuscaloosa: University of Alabama Press.

Newsom, L. A., \& Deagan, K. (1994). Zea mays in the West Indies: the archaeological and early historic record. In S. Johansen \& C. Hastorf (Eds.), Corn and culture in the prehistoric New World (pp. 203-217). San Francisco: Westview Press.

Newsom, L. A., \& Pearsall, D. M. (2003). Trends in Caribbean Island archaeobotany. In P. Minnis (Ed.), People and plants in Ancient Eastern North America (pp. 347-412). Washington D.C.: Smithsonian Institution Press.

Newsom, L. A., \& Wing, E. S. (2004). On land and sea: Native American uses of biological resources in the West Indies (Vol. 45879). Tuscaloosa: University of Alabama Press.

O’Brien, M. J., Lyman, R. L., Mesoudi, A., \& VanPool, T. L. (2010). Cultural traits as units of analysis. Philosophical Transactions of the Royal Society of London. Series B, Biological Sciences, 365(1559), 3797-3806. https://doi.org/10.1098/rstb.2010.0012.

Odling-Smee, F. J., Laland, K. N., \& Feldman, M. W. (2003). Niche construction: the neglected process in evolution. Princeton: Princeton university press.

Pagán-Jiménez, J. R. (2007). De antiguos pueblos y culturas botánicas en el Puerto Rico indigena: el archipiélago borincano y la llegada de los primeros pobladores agroceramistas, Paris Monographs in American Archaeology Series 18, British Archaeological Reports International Series 1687 (Vol. 1067, Paris Monographs in American Archaeology Series 18). Oxford: Archaeopress.

Pagán-Jiménez, J. R. (2008). Envisioning Ancient Human Plant Use at the Rio Tanamá Site 2 (AR-39) through Starch Analysis of Lithic and Clay Griddle Implements. In L. A. Carlson (Ed.), A multidisciplinary approach to the data recovery at two village sites on the Rio Tanamá (pp. 241-257). Copy available at the Puerto Rico State Historic Preservation Office, San Juan.: Southeastern Archaeological Research, US Corps of Engineers, Jacksonville, Florida.

Pagán-Jiménez, J. R. (2009). Nuevas perspectivas sobre las culturas botánicas precolombinas de Puerto Rico: implicaciones del estudio de almidones en herramientas líticas, cerámicas y de concha. Cuba Arqueológica, 2, 7-23.

Pagán-Jiménez, J. R. (2010). Reporte de estudio de almidones en los sitios Popi y Edilio Cruz. Proyecto Arqueológico Macorix de Arriba. In Manuscript in archive. Santo Domingo: Museo del Hombre.

Pagán-Jiménez, J. R. (2011a). Assessing ethnobotanical dynamics at C.E.-11 and C.E.-33 through analysis of starch grains, plant processing, and cooking artifacts. In L. A. Carlson \& J. Torres (Eds.), Phase III data recovery investigations at three prehistoric archaeological sites (CE.-11, CE.-32, and CE.-33), Municipality of Ceiba, Naval Activity Puerto Rico. Southeastern Archaeological Research, Florida (pp. 325-375). San Juan: Copy available at the Puerto Rico State Historic Preservation Office. 
Pagán-Jiménez, J. R. (2011b). Dinámicas fitoculturales de un pueblo precolombino Saladoide tardio (King’s Helmet) en Yabucoa, Puerto Rico. El Caribe Arqueológico, 12, 45-59.

Pagán-Jiménez, J. R. (2012). Early use of maize and other food crops among Early Ceramic and later Neoindian traditions of northeastern Amazonia revealed by ancient starch grains from ceramic and lithic artifacts of the Chemin Saint-Louis archaeological site, French Guiana. Archaeology and Anthropology, 17(2), 78-107.

Pagán-Jiménez, J. R. (2013). Human-plant dynamics in the precolonial Antilles. In W. F. Keegan, C. L. Hofman, \& R. Rodríguez Ramos (Eds.), The Oxford handbook of Caribbean archaeology (pp. 391-406). New York: Oxford University Press.

Pagán-Jiménez, J. R. (2015a). Almidones. Guía de material comparativo moderno del ecuador para los estudios paleoetnobotánicos en el Neotrópico. Buenos Aires: ASPHA.

Pagán-Jiménez, J. R. (2015b). Evaluando algunos mecanismos de conservación/degradación en almidones modernos por medio de ensayos y experimentos controlados que replican ciertas formas antiguas de procesamiento y cocción de órganos almidonosos. Elaboración de dos tipos de chicha de maiz: chicha fermentada con saliva y otra con levadura. (pp. 17): Instituto Nacional de Patrimonio Cultural, Quito.

Pagán-Jiménez, J. R. (2016). Useful starchy plants identified in plant processing/cooking artifacts from the Troumassoid archaeological site of Anse Trabaud, Martinique (final report) (p. 10). Leiden: Faculty of Archaeology, Leiden University.

Pagán-Jiménez in Oliver, J. R. (2014). Nuevos aportes a la arqueología del sitio el saladero, bajo Orinoco, Venezuela. In S. Rostain (Ed.), Actas Del Tercer Encuentro Internacional de Arqueología Amazónica (pp. 97-112). Quito: Instituto Francés de Estudios Andinos.

Pagán-Jiménez in Ulloa Hung, J. (2014). Arqueología en la Linea Noroeste de La Española. Paisaje, cerámicas e interacciones. Santo Domingo: Leiden University.

Pagán-Jiménez, J. R., \& Oliver, J. R. (2008). Starch residues on lithic artifacts from two contrasting contexts in Northwestern Puerto Rico: Los Muertos Cave and Vega de Nelo Vargas. In C. L. Hofman, M. L. P. Hoogland, \& A. L. van Gijn (Eds.), Crossing the borders: new methods and techniques in the study of archaeological materials from the Caribbean (pp. 137-158). Tuscaloosa: University of Alabama Press.

Pagán-Jiménez, J. R., Rodríguez López, M. A., Chanlatte Baik, L. A., \& Narganes Storde, Y. (2005). La temprana introducción y uso de algunas plantas domésticas, silvestres y cultivos en Las Antillas precolombinas. Una Primera Revaloración desde la Perspectiva del "Arcaico" de Vieques y Puerto Rico. Diálogo Antropológico, 3(10), 7-33.

Pagán-Jiménez, J. R., Rodríguez-Ramos, R., Reid, B. A., van den Bel, M., \& Hofman, C. L. (2015). Early dispersals of maize and other food plants into the Southern Caribbean and Northeastern South America. Quaternary Science Reviews, 123, 231-246. https://doi.org/10.1016/j.quascirev2015.07.005.

Pagán-Jiménez, J. R., Guachamín-Tello, A. M., Romero-Bastidas, M. E., \& Constantine-Castro, A. R. (2016). Late ninth millennium B.P. use of Zea mays L. at Cubilán area, highland Ecuador, revealed by ancient starches. Quaternary International, 404, 137-155. https://doi.org/10.1016/j.quaint.2015.08.025.

Pagán-Jiménez, J. R., Guachamín-Tello, A. M., Romero-Bastidas, M. E., \& Vásquez-Ponce, P. X. (2017). Cocción experimental de tortillas de casabe (Manihot esculenta Crantz) y de camote (Ipomoea batatas [L.] Lam.) en planchas de barro: evaluando sus efectos en la morfometría de los almidones desde una perspectiva paleoetnobotánica. Americae, 2, 27-44.

Pagán-Jiménez, J. R., Rodríguez Ramos, R., \& Hofman, C. L. (2019). On the way to the islands: The role of domestic plants in the initial peopling of the Antilles. In C. L. Hofman \& A. Antczak (Eds.), Early Settlers of the Caribbean: Dearchaizing the Archaic. Leiden: Sidestone Press.

Pané, R. (1999 [1571). [Trans. Griswold, S. C.] An account of the antiquities of the Indians: a new edition with an introductory study, notes and appendixes by José Juan Arrom. Durham: Duke University Press.

Pearsall, D. M. (1983). Plant utilization at the Krum Bay Site, St. Thomas, United States Virgin Islands. In E. R. Lundberg (Ed.), Preceramic procurement patterns at Krum Bay, Virgin Islands (pp. 290-361). UrbanaChampaign: University of Illinois.

Pearsall, D. M. (1985). Analysis of soil phytoliths and botanical macroremains from El Bronce archaeological site, Ponce, Puerto Rico. In L. S. Robinson, E. R. Lundberg, \& J. B. Walker (Eds.), Archaeological data recovery at El Bronce, Puerto Rico: Final Report, Phase, 2 (pp. B1-B46).

Pearsall, D. M. (1989). Final report on analysis of macroremains and phytoliths from the Three Dog Site, San Salvador, Bahamas. Manuscript on file, American Archaeology Division: Department of Anthropology, University of Missouri, Columbia.

Pearsall, D. M. (2003). Plant food resources of the Ecuadorian Formative: an overview and comparison to the Central Andes. In R. J. S., \& B. R. L. (Ed.), Archaeology of formative Ecuador (pp. 213-257). Washington, DC: Dumbarton Oaks. 
Pearsall, D. M. (2018). Case studies in paleoethnobotany: understanding ancient lifeways through the study of phytoliths, starch, macroremains, and pollen. Abingdon: Routledge.

Pearsall, D. M., Chandler-Ezell, K., \& Zeidler, J. A. (2004). Maize in ancient Ecuador: results of residue analysis of stone tools from the Real Alto site. Journal of Archaeological Science, 31(4), 423-442. https://doi.org/10.1016/j.jas.2003.09.010.

Pennington, C. W. (1963). The Tarahumar of Mexico: their environment and material culture (Repr.. ed.). Salt Lake City: University of Utah Press.

Perry, L. (2002). Starch analyses reveal multiple functions of quartz "Manioc" grater flakes from the Orinoco Basin, Venezuela. Interciencia, 27(11), 635-639.

Perry, L. (2005). Reassessing the traditional interpretation of "Manioc" artifacts in the Orinoco Valley of Venezuela. Latin American Antiquity, 16(4), 409-426. https://doi.org/10.2307/30042507.

Perry, L. (2010). Starch extraction protocol http://fossilfarm.org/Methods/Methods/Protocol.html. Accessed 17 Sept 2016

Perry, L., Dickau, R., Zarrillo, S., Holst, I., Pearsall, D. M., Piperno, D. R., Berman, M. J., Cooke, R. G., Rademaker, K., Ranere, A. J., Raymond, J. S., Sandweiss, D. H., Scaramelli, F., Tarble, K., \& Zeidler, J. A. (2007). Starch fossils and the domestication and dispersal of chili peppers (Capsicum spp. L.) in the Americas. Science, 315(5814), 986-988. https://doi.org/10.1126/science.1136914.

Piperno, D. R. (2006). Identifying manioc (Manihot esculenta Crantz) and other crops in pre-Columbian tropical America through starch grain analysis: a case study from central Panama. In Z. M.A., B. D.G., E. E., \& S. B.D (Ed.), Documenting domestication: new genetic and archaeological paradigms (pp. 46-67). Berkeley: University of California Press.

Piperno, D. R. (2011). The origins of plant cultivation and domestication in the New World tropics patterns, process, and new developments. Current Anthropology, 52(S4), S453-S470. https:/doi.org/10.1086 $/ 659998$.

Piperno, D. R., \& Dillehay, T. D. (2008). Starch grains on human teeth reveal early broad crop diet in northern Peru. Proceedings of the National Academy of Sciences of the United States of America, 105(50), 1962219627. https://doi.org/10.1073/pnas.0808752105.

Piperno, D. R., \& Holst, I. (1998). The presence of starch grains on prehistoric stone tools from the humid neotropics: Indications of early tuber use and agriculture in Panama. Journal of Archaeological Science, 25(8), 765-776. https://doi.org/10.1006/jasc.1997.0258.

Piperno, D. R., \& Pearsall, D. M. (1998). The origins of agriculture in the lowland Neotropics. In San Diego. California: Academic.

Piperno, D. R., Ranere, A. J., Holst, I., \& Hansell, P. (2000). Starch grains reveal early root crop horticulture in the Panamanian tropical forest. Nature, 407(6806), 894-897. https://doi.org/10.1038/35038055.

Piperno, D. R., Weiss, E., Holst, I., \& Nadel, D. (2004). Processing of wild cereal grains in the Upper Palaeolithic revealed by starch grain analysis. Nature, 430(7000), 670-673. https://doi.org/10.1038 /nature 02734 .

Piperno, D. R., Ranere, A. J., Holst, I., Iriarte, J., \& Dickau, R. (2009). Starch grain and phytolith evidence for early ninth millennium B.P. maize from the Central Balsas River Valley, Mexico. Proceedings of the National Academy of Sciences of the United States of America, 106(13), 5019-5024. https://doi. org/10.1073/pnas.0812525106.

Reichert, E. T. (1913). The differentiation and specificity of starches in relation to genera, species, etc: stereochemistry applied to protoplasmic processes and products, and as a strictly scientific basis for the classification of plants and animals (Vol. 173). Washington, D. C: Carnegie institution of Washington.

Reyna Alcántara, E., \& Polonia Martínez, A. (2012). Atlas de Biodiversidad y Recursos Naturales de la República Dominicana. Santo Domingo: Marzo.

Rodríguez Ramos, R. (2010). What is the Caribbean? An archaeological perspective. Journal of Caribbean Archaeology, 3, 19-51.

Rodríguez Ramos, R. (2011). Close encounters of the Caribbean kind. In L. A. Curet \& M. W. Hauser (Eds.), Islands at the crossroads: migration, seafaring, and interaction in the Caribbean (pp. 164-192). Tuscaloosa: University of Alabama Press.

Rodríguez Ramos, R. (2016). Recent advances in the archaeology of the Greater Antilles. In I. Roksandic (Ed.), Cuban archaeology in the Caribbean (pp. 228-240). Gainesville University Press of Florida.

Rodríguez Ramos, R., Pagán-Jiménez, J. R., \& Hofman, C. L. (2013a). The humanization of the insular Caribbean. In W. F. Keegan, C. L. Hofman, \& R. Rodríguez Ramos (Eds.), The Oxford handbook of Caribbean archaeology (pp. 126-140). New York: Oxford University Press.

Rodríguez Ramos, R., Pagán-Jiménez, J. R., Santiago-Blay, J., Lambert, J. B., \& Craig, P. R. (2013b). Some indigenous uses of plants in pre-Columbian Puerto Rico. Life Excit. Biol., 1(1), 83-90. 
Rodríguez Suárez, R. (2001). El burén como artefacto multipropósito en la cocina prehispánica de comunidades agroalfareras de Cuba. Paper presented at the the Segundo Coloquio Nacional de Arqueometría, UNAM, Mexico City,

Rodríguez Suárez, R. (2004). Huellas de restos en la cerámica precolombina: El caso del sitio Lagunas de Limonas, Maisí, Cuba. El Caribe Arqueológico, 8, 86-90.

Rodríguez Suárez, R., \& Pagán-Jiménez, J. R. (2008). The Burén in precolonial Cuban archaeology: new information regarding the use of plants and ceramic griddles during the Late Ceramic Age of Eastern Cuba gathered through starch analysis. In C. L. Hofman, M. L. P. Hoogland, \& A. L. Van Gijn (Eds.), Crossing the borders, new methods and techniques in the study of archaeological materials from the Caribbean (pp. 159-169). Tuscaloosa: The University of Alabama Press.

Rosenswig, R. M., Pearsall, D. M., Masson, M. A., Culleton, B. J., \& Kennett, D. J. (2014). Archaic period settlement and subsistence in the Maya lowlands: new starch grain and lithic data from Freshwater Creek, Belize. Journal of Archaeological Science, 41, 308-321. https://doi.org/10.1016/j.jas.2013.07.034.

Rouse, I. (1941). Culture of the Ft. Liberté Region, Haiti. New Haven: Yale University Publications in Anthropology.

Rouse, I. (1992). The Tainos, rise and decline of the people who greeted Columbus. New Haven: Yale University Press.

Sears, W. H., \& Sullivan, S. O. (1978). Bahamas prehistory. American Antiquity, 43(1), 3-25. https://doi. org/10.2307/279627.

Sheets, P., Lentz, D., Piperno, D. R., Jones, J., Dixon, C., Maloof, G., et al. (2012). Ancient manioc agriculture south of the Cerén village, El Salvador. Latin American Antiquity, 23(3), 259-281.

Shev, G. T. (2018). Feeding Opiyelguobirán: a multi-disciplinary analysis of human-canid relations in precolonial Hispaniola. Leiden University, Unpublished Master's Thesis.

Sinelli, P. T. (2010). All islands great and small: the role of small cay environments in indigenous settlement strategies in the Turks \& Caicos Islands.

Sinelli, P. T. (2013). Meillacoid and the origins of classic Taino society. In W. F. Keegan, C. L. Hofman, \& R. Rodríguez Ramos (Eds.), The Oxford handbook of Caribbean archaeology. New York: Oxford University Press Oxford.

Sinelli, P. T. (2015). Migrating Meillacoid, or: how I learned to stop worrying and love the Bahamas. Paper presented at the 25th Congress of the IACA, Sint Maarten,

Smith, E. A. (2013). Agency and adaptation: new directions in evolutionary anthropology. Annual Review of Anthropology, 42(1), 103-120. https://doi.org/10.1146/annurev-anthro-092412-155447.

Smith, B. D. (2015). A comparison of niche construction theory and diet breadth models as explanatory frameworks for the initial domestication of plants and animals. Journal of Archaeological Research, 23(3), 215-262. https://doi.org/10.1007/s10814-015-9081-4.

Smith, B. D. (2016). Neo-Darwinism, niche construction theory, and the initial domestication of plants and animals. Evolutionary Ecology, 30(2), 307-324. https://doi.org/10.1007/s10682-015-9797-0.

Smith, D. G., \& Chinique de Armas, Y. (2018). Straddling the subsistence divide: the case of Canímar Abajo and contemporaneous sites in Northwestern Cuba. In B. A. Reid (Ed.), The archaeology of Caribbean and Circum-Caribbean farmers (6000 BC-AD 1500) (pp. 126-140). London: Routledge.

Staller, J., Tykot, R., \& Benz, B. (2006). Histories of maize: Multidisciplinary approaches to the prehistory, linguistics, biogeography, domestication, and evolution of maize. Amsterdam: Academic.

Therin, M., Fullagar, R., \& Torrence, R. (1999). Starch in sediments: a new approach to the study of subsistence and land use in Papua New Guinea. In C. Godsen \& J. Hather (Eds.), The prehistory of change. Appetites for change (pp. 438-464). London: Routledge.

Tian, F., Stevens, N. M., \& Buckler, E. S. T. (2009). Tracking footprints of maize domestication and evidence for a massive selective sweep on chromosome 10. Proc Natl Acad Sci U S A, 106(Suppl 1), 9979-9986. https://doi.org/10.1073/pnas.0901122106.

Ting, C., Neyt, B., Ulloa Hung, J., Hofman, C. L., \& Degryse, P. (2016). The production of pre-colonial ceramics in northwestern Hispaniola: a technological study of Meillacoid and Chicoid ceramics from La Luperona and El Flaco, Dominican Republic. Journal of Archaeological Science-Reports, 6, 376-385. https://doi.org/10.1016/j.jasrep.2016.02.031.

Twiss, K. C. (2007). We are what we eat. In K. C. Twiss (Ed.), The archaeology of food and identity (Vol. 34, pp. 1-15). Carbondale: Center for Archaeological Investigations, Southern Illinois University Carbondale.

van den Bel, M. (2009). The Palikur Potters: an ethnoarchaeological case study on the Palikur pottery tradition in French-Guiana and Amapá, Brazil. Boletim do Museu Paraense Emílio Goeldi. Ciências Humanas, 4(1), 39-56. 
van den Bel, M., Pagán Jiménez, J. R., \& Fronteau, G. (2013). Le Rorota Revisité: Résultats Des Fouilles Préventives Au PK 11, Route Des Plages, Île de Cayenne. In B. Berard (Ed.), Actes Du 24 Congres de l'AIAC, Martinique (pp. 189-209). International Association for Caribbean Archaeology.

van den Bel, M., Knippenberg, S., \& Pagán-Jiménez, J. R. (2018). From cooking pits to cooking pots. Changing modes of food processing during the Late Archaic Age in French Guiana. In B. A. Reid (Ed.), The archaeology of Caribbean and Circum-Caribbean farmers (6000 BC-AD 1500) (pp. 391-418). London: Routledge.

Vinton, S. D., Perry, L., Reinhard, K. J., Santoro, C. M., \& Teixeira-Santos, I. (2009). Impact of empire expansion on household diet: the Inka in Northern Chile's Atacama Desert. PLoS One, 4(11), e8069. https://doi.org/10.1371/journal.pone.0008069.

Wang, J. J., Liu, L., Georgescu, A., Le, V. V., Ota, M. H., Tang, S. L., et al. (2017). Identifying ancient beer brewing through starch analysis: a methodology. Journal of Archaeological Science-Reports, 15, 150160. https://doi.org/10.1016/j.jasrep.2017.07.016.

Welch, P. D., \& Scarry, C. M. (1995). Status-related variation in foodways in the Moundville Chiefdom. American Antiquity, 60(3), 397-419. https://doi.org/10.2307/282257.

Wilson, S. M. (1993). The cultural mosaic of the prehistoric Caribbean. Proceedings of the British Academy, $81,37-66$.

Wilson, S. M. (2007). The archaeology of the Caribbean. Cambridge: Cambridge University Press.

Winter, J. (1978). A note on Bahamian griddles. In J. Benoist \& F. M. Mayer (Eds.), Proceedings of the Seventh International Congress for the Study of Pre-Columbian Cultures of the Lesser Antilles. Centre de Recherches Caralbes (pp. 232-236). Montreal: Montréal.

Wobst, H. M. (1978). The archaeo-ethnology of hunter-gatherers or the tyranny of the ethnographic record in archaeology. American Antiquity, 43(2), 303-309.

Wylie, A. M. (1985). The reaction against analogy. In M. B. Schiffer (Ed.), Advances in archaeological method and theory (Vol. 8, pp. 63-111). Orlando: Academic.

Zarrillo, S. (2012). Human adaptation, food production, and cultural interaction during the Formative Period in Highland Ecuador. PhD diss., University of Calgary.

Zarrillo, S., Pearsall, D. M., Raymond, J. S., Tisdale, M. A., \& Quon, D. J. (2008). Directly dated starch residues document early formative maize (Zea mays L.) in tropical Ecuador. Proceedings of the National Academy of Sciences of the United States of America, 105(13), 5006-5011. https://doi.org/10.1073 /pnas.0800894105.

Zarrillo, S., Gaikwad, N., Lanaud, C., Powis, T., Viot, C., Lesur, I., Fouet, O., Argout, X., Guichoux, E., Salin, F., Solorzano, R. L., Bouchez, O., Vignes, H., Severts, P., Hurtado, J., Yepez, A., Grivetti, L., Blake, M., \& Valdez, F. (2018). The use and domestication of Theobroma cacao during the mid-Holocene in the upper Amazon. Nature Ecology Evolution, 2(12), 1879-1888. https://doi.org/10.1038/s41559-018-0697-x.

Zeder, M. A. (2015). Core questions in domestication research. Proceedings of the National Academy of Sciences of the United States of America, 112(11), 3191-3198. https://doi.org/10.1073/pnas. 1501711112.

Zeder, M. A. (2016). Domestication as a model system for niche construction theory. Evolutionary Ecology, 30(2), 325-348. https://doi.org/10.1007/s10682-015-9801-8.

Publisher's Note Springer Nature remains neutral with regard to jurisdictional claims in published maps and institutional affiliations. 